\title{
Credit Constraints in Manufacturing Enterprises in Africa
}

\author{
WPS/2000.24
}

\author{
Arne Bigsten 1 , Paul Collier ${ }^{8}$, Stefan Dercon ${ }^{2,3}$, Marcel Fafchamps ${ }^{2}$, \\ Bernard Gauthier $^{4}$, Jan Willem Gunning ${ }^{6}$, Mans Soderbom ${ }^{2}$, Abena Oduro ${ }^{5}$, \\ Remco Oostendorp ${ }^{6}$, Cathy Patillo ${ }^{8}$, Francis Teal ${ }^{2}$, Albert Zeufack ${ }^{7}$
}

We investigate the question whether firms in the manufacturing sector in Africa are credit constrained. The fact that few firms obtain credit is not sufficient to prove constraints, since certain firms may not have a demand for credit while others may be refused credit as part of profit maximising behaviour by banks. To investigate this question, we use direct evidence on whether firms had a demand of credit and whether their demand was satisfied in the formal credit market, based on panel data on firms in the manufacturing sector from six African countries. More than half the firms in the sample had no demand for credit. Of those firms with a demand for credit, only a quarter obtained a formal sector loan. In line with expectations, our analysis suggests that banks allocate credit on the basis of expected profits. However, controlling for credit demand, outstanding debt is positively related with obtaining further lending while micro or small firms are less likely to get a loan than large firms. The latter effect is strong and present in the regression, despite including several variables typically referred to as explaining why small or 'informal' firms do not get credit. The role of outstanding debt is likely to be a reflection of inefficiency in credit markets, while the fact that size matters is consistent with a bias as well, although we cannot totally exclude that they reflect transactions costs on the part of banks. Finally, we could not detect any differences between countries in the effects of these factors in the credit allocation rule, although financial deepening is found to explain most of the country-specific fixed effects, shifting the probability of obtaining credit across the firm distribution.

Revised September 2000

The authors form the ISA (Industrial Surveys in Africa) Group, which uses multi-country data sets to analyse the microeconomics of industrial performance in Africa. ${ }^{1}$ University of Gothenburg, ${ }^{2}$ University of Oxford, ${ }^{3}$ Katholieke Universiteit Leuven, ${ }^{4}$ Centre d'Etudes en Administration International, Montreal, ${ }^{5}$ University of Ghana, Legon, ${ }^{6}$ Free University Amsterdam, ${ }^{7}$ World Bank, ${ }^{8}$ Research Department IMF. 


\section{Introduction}

Credit programmes have long been a favoured intervention by donors and governments in Africa. Implicit in these interventions is a concern that credit markets are not functioning well and that their malfunctioning results in low economic activity and growth. There are well-established reasons for credit markets not to be perfect (for a review see Hoff et al. (1993)). Given the intertemporal and risky nature of credit trade, the informational requirements and enforcement problems are large and agency costs will affect the outcome. The consequence is that uncollateralised lending will not take place at current real interest rates, i.e. the borrower cannot be a price taker. The borrower will be constrained by being forced to borrow money at higher interest rates to cover monitoring and enforcement costs or, as is usually the case, be rationed by not being allowed to borrow at all at these interest rates. In either case, less lending takes place than if there were no monitoring problems. Enforcement problems would further reduce credit market transactions.

While the theoretical grounds for credit market imperfections are well-known, the empirical evidence on their existence and on their consequences for economic activity and growth are far less well established, both in industrialised countries and in developing regions like Africa. In this paper, we make use of firm-level data from six African countries to study both the existence and nature of credit constraints. We use evidence on credit market participation and on the reasons for non-credit market participation to identify possibly constrained firms. We investigate whether agency and enforcement costs, or limited demand are at the root of non-participation in credit markets by firms. We also try to identify whether the banks' lending policy is biased against certain firms, beyond monitoring and enforcement problems. Many interventions favour credit to small-scale enterprises, implicitly suggesting that these imperfections can be overcome.

We use data on six countries: Ghana, Zimbabwe, Kenya, Côte d'Ivoire, Burundi, and Cameroon. The data were collected between 1992 and 1996 on a sample of manufacturing enterprises as part of the Regional Program for Enterprise Development (RPED), implemented by different teams and co-ordinated by the World Bank. Using the same sample, Biggs and Srivastava (1997) discuss the salient features of the credit transactions in the data sets. Fisman (1998) and Fafchamps $(1997,2000)$ have analysed trade credit transactions in these data. Using credit data from one round of the Zimbabwe survey, Raturi and Swamy (1999) analyse whether ethnic differences result in constraints in the formal credit market. In this paper, we focus specifically on whether credit market constraints are similar across countries and whether small firms face a bias in lending by banks and financial institutions.

The paper is organised as follows. In the next section, we discuss the problems of identifying credit constraints using firm level data and construct an empirical model for analysing the problem. In section 3 we present the data and provide some context on credit markets in the different countries. In this section, we attempt to distinguish firms according to their credit market participation and their credit demand. We investigate whether they are constrained in the credit market. In section 4, the econometric model is presented and the variables included in the analysis are discussed. The results are in section 5. Section 6 concludes. 


\section{Identifying and modelling credit constraints}

There is a vast literature on firm-level credit constraints in developed and developing countries. Most of the empirical literature focuses on the consequences of credit contraints in a standard neoclassical investment model (e.g. Fazzari et al. (1988), Bond and Meghir (1994), Scianterelli (1996), Hubbard (1998)). Under a perfectly competitive credit markets, any financial information about the firm should be orthogonal to investment decisions and therefore to the investment path. In particular, following Miller-Modigliani's theorem, firms should be indifferent between internal and external sources of funds, so any information related to the current liquidity of the firm (or other information related to the capital structure and asset position of the firm) should be irrelevant for investment. The standard test for credit constraints consists of adding overidentifying restrictions to an equation describing the investment path, such as an Euler equation or a flexible accelerator model. In most tests, significant effects on the overidentifying restrictions have been found, leading to the conclusion that credit constraints matter for investment, and by implication that firms are credit constrained. However, in this literature the question is rarely asked whether there is direct evidence on the failure to participate in the credit market on the part of the firms in question, or more generally that the problems are indeed linked with problems in credit market functioning ${ }^{1}$.

In this paper, we are not taking this standard route, but look for more direct evidence on credit market participation and constraints faced by firms. We try to model explicitly the demand for external funds of firms and try to assess the apparent decision rules applied by financial institutions to grant loans. We model the loan allocation process in two stages. First, the firm decides whether it wants to use liquidity for its business and whether it will apply for external funds for this purpose. Then, the loan is approved or not and investment plans implemented or adjusted accordingly. For the time being, we ignore the issue whether the firm wants to expand (invest), finance inventories or needs working capital for its operations. In the model, we focus on the first issue.

Applying for loans implies transactions costs, in terms of preparation costs for the application and waiting time. As an alternative means of financing investment, we allow firms to build up internal funds, based on retained profits. Formally, we assume that firms maximise the stream of dividends to the owner (shareholders). Let $d_{t}$ be the dividends paid in period $\mathrm{t}$ and $\mathrm{u}\left(\mathrm{d}_{\mathrm{t}}\right)$ be the instantaneous utility derived from this dividend. We assume risk aversion $\left(u^{\prime}>0, u^{\prime},<0\right)$ and that the owner maximises expected utility at $\mathrm{t}$, with $\theta$ the rate of time preference:

$$
E \sum_{\tau=t}^{T}\left(\frac{1}{1+\theta}\right)^{\tau-t} u\left(d_{\tau}\right)
$$

\footnotetext{
${ }^{1}$ In the literature on developing countries, Tybout (1983) and Nabi (1989) are exceptions. Tybout (1983) provides an econometric analysis of the effects of credit market rationing on investment using data from Colombia. Nabi (1989) explicitly models credit rationing in a repressed financial system as a first step in a switching regression of investment. However, the underlying assumption in his model is that interest rates are so low that all firms want (infinite) credit to invest. Consequently, the choice between internal and external funds is irrelevant.
} 
We define an asset equation for internal funds $F_{t+1}$ consisting of initial internal funds ('bank deposits') which earned an interest rate $r$, profits at $t\left(\pi_{t}\right)$ and any loans $B$ received at $t$. From this, we subtract repayment of debt inclusive of interest payments $(1+\mathrm{i}) \mathrm{B}_{\mathrm{t}-1}{ }^{2}$, dividend payments at $\mathrm{t}$ and investment $\mathrm{q}_{\mathrm{t}} \mathrm{I}_{\mathrm{t}}$ in which $\mathrm{q}_{\mathrm{t}}$ is the price of investment goods, i.e.:

$$
F_{t+1}=(1+r) F_{t}+\pi_{t}+B_{t}-(1+i) B_{t-1}-q_{t} I_{t}-d_{t}
$$

We assume that loan applications at $t\left(A_{t}\right)$ will only be approved (if at all) in period $t+1$. Loans obtained $B_{t}$ equal $g\left(A_{t-1}\right)$. In general, an amount $B_{t}$ is obtained from successful applications for $A_{t-1}$, with a maximum of $A_{t-1}$, while if the application fails 0 is obtained. We simplify this further by assuming that all loans obtained are paid out in full and that the (firm specific) success rate is $s$, so that $E_{t-1}\left(B_{t}\right)=s . A_{t-1} .^{3}$ Applications for a loan do not only cost in terms of time, there are also costs $c\left(A_{t}\right)$ for applying for a loan ${ }^{4}$. We consider costs non-decreasing in $A_{t}\left(c^{\prime} \geq 0\right)$. A plausible assumption in this respect would be to have concave costs $\left(c^{\prime}\right.$ " $\left.<0\right)$, so that small loan applications are relatively more costly.

Let us define $\mathrm{K}_{\mathrm{t}}$ as the capital stock, $\delta$ as the rate of depreciation, product prices $\mathrm{p}_{\mathrm{t}}$, wages $\mathrm{w}_{t}$, labour $\mathrm{L}_{\mathrm{t}}$ and a production function $\mathrm{f}\left(\mathrm{K}_{\mathrm{t}}, \mathrm{L}_{\mathrm{t}}\right)$, risky profits $\pi_{\mathrm{t}}$ and, as before, $\mathrm{q}_{\mathrm{t}}$ as the price of capital (investment) goods. The capital asset equation can then be defined as ${ }^{5}$ :

$$
\begin{gathered}
\pi_{t}=p_{t} f\left(K_{t}, L_{t}\right)-w_{t} L_{t}-c\left(A_{t}\right) \\
q_{t+1} K_{t+1}=(1-\delta) q_{t} K_{t}+q_{t} I_{t}
\end{gathered}
$$

We also impose a constraint on the value of loan applications, in that the firm's current balance sheet must be providing sufficient net assets (capital goods plus internal funds minus outstanding debt) to serve as collateral for the loan application, but allowing for some firm specific constant $\underline{B}$ :

$$
A_{t} \leq q_{t} K_{t}+F_{t}-(1+i) B_{t-1}+\underline{B}
$$

Condition (5) can be viewed as a collateral constraint, although firm-specific circumstances (such as owner's assets, other guarantees, networks with banks and others, extensive past banking relationships, and other reputational devices) may affect the ability to borrow despite the agency and enforcement problems involved in uncollateralised borrowing. We do not exclude the possibility that $\underline{B}$ is negative:

\footnotetext{
${ }^{2}$ Note that, for simplicity, we assume that loans are only obtained for one year, after which they need to be repaid with interest and new funds may have to raised. The consequence is that the stock of debt and any new lending is both denoted by B, saving on notation. Extending this for long term loans does not change the outcome of the model.

${ }^{3}$ We use standard assumptions for the production function $\left(f_{K}, f_{L}>0\right.$ and $\left.f_{K K}, f_{L L}<0\right)$. The success rate is assumed to be independent of other risks facing the firm.

${ }^{4}$ Bernanke and Gertler (1989) introduce a similar cost element in using external funds, which they consider as the cost for titling or auditing when participating in the formal credit market, rather than using internal funds.

${ }^{5}$ For simplicity, risk is assumed to stem from output prices or from risk in the production function. We assume increasing returns to each factor, but at a decreasing rate $\left(f_{L}, f_{K}>0, f_{L L}, f_{K K}<0\right)$.
} 
contract enforcement problems may mean that banks do not wish to lend to particular firms, despite the presence of collateral and stipulate other conditions (e.g. residency, etc.) on loan application. Note that the success rate s related to loan applications, is influenced by similar firm-specific factors.

Finally, non-negativity constraints apply to internal funds, net assets and (applications for) external funds in each period:

$$
\begin{gathered}
F_{t} \geq 0 \\
q_{t} K_{t}+F_{t}-(1+i) B_{t-1} \geq 0 \\
A_{t} \geq 0
\end{gathered}
$$

Note that (8) (non-negative loan applications) and (5) (the collateral constraint) imply (7) (which can be viewed as a bankruptcy constraint), so the latter does not need to be considered separately further. Except for the detail on the choices between applying for a loan or only using internal funds for financing investment and the presence of credit constraints via (5), this is a standard investment model. First-order conditions are therefore straightforwardly stated. First, owners will try to obtain a smooth flow of dividends, but may be constrained by the internal funds constraint (6). In particular, the optimal path of dividends will follow:

$$
u^{\prime}\left(d_{t}\right)=\frac{1+r}{1+\theta} E_{t}\left[u^{\prime}\left(d_{t+1}\right)\right]+\lambda_{1 t}
$$

in which $\lambda_{1}$ is the shadow cost (Langrange multiplier) on the nonnegativity constraint on internal funds (6). If it binds, then current dividends are lower than preferred by the owner, i.e. more funds need to be kept in the firm. Given the current cash flow, firms have the choice between investing in the firm or keeping the cash as internal funds, with firms investing in the firm (assuming positive $\mathrm{K}_{\mathrm{t}}$ to start with) until:

$$
E_{t}\left[\left(\frac{p_{t+1} f_{K_{t+1}}-\delta+(1-\delta)\left(q_{t+1}-q_{t}\right)}{q_{t}}-r\right) \mu^{\prime}\left(d_{t+1}\right)\right]=\lambda_{1 t}
$$

Equation (10) illustrates the consequence of the existence of the cash flow constraint: if the constraint is binding, then investment will be lower than optimal, with marginal returns to capital larger than marginal and opportunity costs of investing in capital. Note that this situation may come about because of low current profits, high past debt, low initial internal funds or loans that were not approved. If the internal funds constraint is not binding, then (10) simply reduces to the condition that user cost of capital should in the optimum be equal to the return ${ }^{6}$.

Finally, we can derive the condition for loan applications by the firm. This is effectively a choice between putting in for a loan for an investment (or another purpose) and incurring some costs and interest charges, or using this money directly for the investment. Let $\lambda_{2 t}$ and $\lambda_{3 t}$ be the shadow cost (Lagrange multipliers) for the collateral and non-negativity constraints (5) and (7). Then loan applications will satisfy the following Kuhn-Tucker condition:

\footnotetext{
${ }^{6}$ Note that in this model, firms never have too much capital since they can always sell it. Adjustment costs or irreversibility would change this.
} 


$$
\begin{gathered}
E_{t}\left\lfloor\left(s .\left(R_{I_{t+1}}-i\right)-c^{\prime}\left(A_{t}\right)\left(1+R_{I_{t}}\right)\right) u^{\prime}\left(d_{t+1}\right)\right\rfloor-\lambda_{1 t} c^{\prime}\left(A_{t}\right)-\lambda_{2 t}\left(1+c^{\prime}\left(A_{t}\right)\right)+\lambda_{3 t} \leq 0 \\
\text { with } R_{I t}=\frac{\left(p_{t+1} f_{K_{t+1}}-\delta+(1-\delta)\left(q_{t+1}-q_{t}\right)\right)}{q_{t}}
\end{gathered}
$$

If the firm applies for a loan then $\lambda_{3 t}=0$ and equation (11) is satisfied with equality. If the current cash constraint nor the collateral constraint are binding $\left(\lambda_{1 \mathrm{t}}=0, \lambda_{2 \mathrm{t}}=0\right)$, then firms will spend on loan applications until the marginal utility weighted expected return is equal to their marginal cost. However, the current cash constraint (to pay for the marginal cost of applying) or the collateral constraint could cause unexploited returns to investment via loans relative to returns to cash, taking into account information about the success rate of applications ${ }^{7}$.

Equation (11) shows the circumstances in which firms may not want to apply for loans: low profitability of investment relative to the interest rate on loans and high applications costs could imply no demand for external funds. Low perceived success rates would also reduce actual loan applications despite potentially profitable investments. Firms may be constrained due to credit market imperfections, lacking the cash to pay for the application costs or the collateral due to low current net worth and/or poor firm-specific collateral substitutes: cash and collateral constraints would leave unexploited profits.

The model suggests a way of constructing an empirical model to identify the factors determining the demand for credit and how the market allocates credit across firms. First, we could try to identify the factors determining whether firms have a demand for external funds. From (10) and (11) it follows that, controlling for risk attitudes, the firm will consider:

(a) the expected return on investment,

(b) the opportunity cost of using own funds for this investment (i.e. factors affecting the cash constraint) and

(c) the cost of outside funds (interest rate on loans).

These factors are intrinsically related to investment demand. In a frictionless economy, without adjustment costs or market imperfections, past decisions will have taken into account all information on (a), (b) and (c), so that only new information or shocks would induce investment demand (beyond depreciation). Under certain assumptions, equation (10) could be simplified to yield the well-known martingale property of investment - investment follows a random walk. An implication for credit demand is that credit demand also only responds to shocks. However, this ignores at least two other reasons for demanding credit in any period. First, if adjustment costs in capital allocation are present, then credit demand will be affected by desired capital holdings in each period. Secondly, credit may not just be required for investment, but

\footnotetext{
${ }^{7}$ If investment returns and deposit interest rates are equal, (10) is valid with equality. In that case, without collateral or cash constraints, firms would only apply for loans if expected returns to holding the loan in cash $\mathrm{r}$ are higher than the expected interest rate charges on this loan and the costs of the application. In particular, with non-risky $r$ and $i$, and $s$ independent of other risk, $s . r \geq s . i+c^{\prime}\left(A_{t}\right)(1+r)$. This would only be the case if the borrowing interest rate is low relative to deposit interest rates.
} 
also to provide liquidity for working capital needs. In the empirical model, we will try to take these factors into account as well.

Proxies for the demand for external funds would include new information on changes in the general or sectoral economic conditions, etc. Desired capital stock and past investment will provide information as well. Working capital needs may be proxied by cash flow or access to alternative short term financing, such as overdrafts. The opportunity cost of using own funds is affected by the liquidity of the firm: profits, cash flow, access to overdraft facilities and to other sources of credit, such as informal loans. Finally, although not explicitly modelled, given limited liability, firms have incentives to express a demand for credit to finance risky projects while using own funds for safe projects, which with imperfect information, may give rise to adverse selection problems in the credit market.

However, given credit market imperfections, firms may prefer external funds to internal funds but would not apply for loans for the following reasons:

(d) collateral requirements are not met or the success rate of applications is less than one, and

(e) the costs associated with loan applications (transactions costs) are too high.

Factors affecting current collateral include assets, outstanding debt, but also opportunities for collateral substitutes, such as ethnicity, networks, legal status, ownership structure, firm age, whether it keeps accounts, links with the financial sector, such as through bank accounts, overdrafts, financing for start-up, etc. Note that these factors may also affect contract enforcement. Any information available to firms on the ways of screening by firms should also be included since it affects the (perceived) success rate for loan applications. Transactions costs may also be affected by these factors, as well as factors such as the characteristics of the owner or manager, location (for example in major cities), scale of activities (firm size), etc. Collateral requirements and transactions costs will imply that there will be firms that do not prefer internal funds to external funds but still not apply for loans. We will consider these firms to be constrained, as will be those firms applying for but not receiving credit. In the empirical analysis, we will attempt to distinguish firms that do not want to participate in credit markets from those apparently constrained by credit market imperfections.

In principle, profit maximising banks would wish to use complete information on firms to assess any loan application. In this respect, they would want to use (a), (c) and (d) to assess any applications, and would find information about the opportunity costs of own funds within the firm also useful. However, in practice they have not the means to collect this information, or transactions and monitoring costs would be too high. We will assume that they form expectations about the expected return on investment using information on sectoral and country-wide conditions, and on firm size and other basic, directly observable firm characteristics. Also, past lending is likely to be observable to the financial sector. Finally, information on collateral requirements and the success rate reflects constraints imposed by the banks, so they are also assumed to be fully observable to them. 
Success rates on loan applications s and the extent to which banks wish to enforce the collateral constraint are determined by the financial sector, even though they may be influenced by firm-specific factors. Agency problems, related to asymmetric information and contract enforcement in the lending market, may mean that credit rationing is optimal for the banks. For example, with adverse selection due to (for the banks) unobservable risk of default among the firms, banks may find it optimal to restrict lending in order to influence the mix of applications. The rationing scheme used by the banks may be random, such that identical firms may be treated differently. In that case, conditional on applications, firm characteristics should not matter in the allocation of credit. Of course, the banking sector has incentives to screen firms. Banks may use firm or sector specific rules to identify the firms to lend to, to maximise its own profits, taking into account any risk aversion they may have. In this respect, the characteristics used to screen may go beyond factors directly related to future profitability of the proposed investment plans of firms, but which matter for the way the banks perceive the risks of the lender. However, this suggests a profit maximising banking sector (allowing for risk attitudes) achieving a constrained Pareto-efficient outcome, even though not all firms may obtain as much credit as they would wish at current terms and conditions. Nevertheless, a common complaint by firms is that credit allocation is not done according to efficiency. If one were to identify the allocation rule used by the banking sector and one finds that this is not consistent with the costs related to agency or enforcement problems, but related to other factors, then one may be able to conclude that credit allocation is indeed inefficient and biased against certain firms. In the econometric analysis, we will try to identify whether this is indeed the case.

\section{Credit market participation by African manufacturing enterprises}

The data used in this paper is a sample drawn from a survey of firms in the manufacturing sectors of Cameroon, Ghana, Kenya, Zimbabwe, Burundi and Côte d'Ivoire, interviewed as part of the RPED-survey programme organised by the World Bank. Firms interviewed range in size from micro (less than five employees) to those employing over a thousand. For four of the countries, three rounds of interviews were conducted over the period 1992 to 1995. In Burundi, only one round of interviews was completed (in 1992). In Côte d'Ivoire two rounds were completed in 1995 and 1996. Firms were selected from four sectors in manufacturing, i.e food, textile, wood and metal. In most countries, a good sampling frame for the smaller or informal sector firms was missing. This has meant that the samples over-represent large and formal sector firms relative to the population. Details on the survey are in Bigsten et al. (1999a) and Biggs and Srivastava (1997). Appendix table 1 gives the dates of the surveys in each of the countries.

In all countries considered, we can find a relatively wide array of financial institutions, with private banks coexisting with banks and financial institutions with mixed or government ownership. Nevertheless, in all countries, private or mixed ownership of banks is prevalent. In some, such as in Zimbabwe, the financial sector is even virtually exclusively private owned; in others, such as in Ghana, some largely government owned non-bank financial institutions exist as well. Kenya, Zimbabwe and Côte d'Ivoire can be considered as having relatively well-developed financial systems (Soyibo (1997)). In all countries, despite the emergence of stock exchanges, capital 
markets remain underdeveloped, implying that equity financing has to come via internal funds or via the credit market. Government involvement in credit market institutions is continuing, as is the banking sectors' role in financing the public sector.

During this period, economic reform was continuing in these economies, including some initiatives related to monetary and banking reform. In the 1970s and 1980s, financial repression, with resulting negative real interest rates and extensive government controls was prevalent in Africa. In recent years, different initiatives as part of structural adjustment programmes have sought to rectify this situation in the economies considered. In Ghana, reforms started early, in 1983, with financial sector reforms since the second part of the 1980s. Gradually, liberalisation of the banking sector resulted in more private sector involvement, but initially the financial infrastructure and legal framework were weak. Since 1989, interest rates are freely determined through inter-bank transactions. In Zimbabwe, interest rates were liberalised as part of the structural adjustment programme (ESAP) in 1990, resulting in very high interest rates in subsequent years. In Cameroon, and to a lesser extent as in Côte d'Ivoire, a crisis developed in the financial and banking system after a serious of shocks in the mid-1980s. Liberalisation in Cameroon was started in 1989, with further financial sector reforms on the agenda. Reforms included the setting up an institution for delinquent loan recovery, debt rescheduling for private banks and the public sector and several regulatory changes. Macroeconomic instability continued well into the 1990s, partly rectified by the devaluation of 1994. The crisis in the banking sector was by no means resolved by these measures.

In Kenya, private sector involvement and diversity in financial services offered has been exceptional for African standards; nevertheless many government controls remained in place at the time of the survey. Since 1991, interest rates have been liberalised. Since then, however, interest rates have often remained negative, probably linked to closely knit business interests, including between public and private sector institutions. Lending by the public sector remains high, crowding out private lending. During the survey period, the system was seriously under threat, with half the banking system in distress or in questionable financial order, mainly linked to poor lending policies. The Ministry of Finance has exempted many banks from regulations under the Banking Act. Property rights on collateral are also poorly enforced by the judicial system.

Table 1 gives an overview of growth, financial deepening and interest rates. During the period 1991-95, Côte d'Ivoire experienced the highest growth rates, but this hides negative growth in the period 1993-94, before the devaluation of the Franc CFA. Ghana continued to grow each year, while stagnation continued in Zimbabwe, Cameroon and Kenya. Real interest rates where only systematically positive in Ghana. In Côte d'Ivoire and Cameroon, they turned strongly negative with relatively high inflation after the devaluation in 1994, which was a temporary effect - high positive rates were noted in the preceding years and afterwards. In Zimbabwe, rates turned strongly positive in the latter part of the period considered. As the discussion above suggested, negative interest rates are usually not linked with official lending policy at cheap rates. In general, nominal interest rates were high in all countries considered and negative rates directly stem from higher inflation than officially foreseen. Observed periods of apparent financial repression mainly stem from macroeconomic 
instability. Finally, in terms of monetary deepening, Côte d'Ivoire and Kenya have the highest degree as measured by M2 over GDP. In general, they can be considered to be low. There is no evidence of a systematic increase in financial deepening in recent years, despite the reforms. In conclusion, due to the lack of well-developed capital markets, the financial sector is the main source for external funds in all countries considered. Liberalisation and reforms have started to open up the banking sector, but concerns about the strength and viability of the system remain in many of these economies. Large fluctuations in real interest rates linked to continuing macroeconomic instability will not contribute to a favourable lending climate. Concerns about the institutional structure and the link with the political establishment remain as well.

Table 1 Monetary deepening, growth and real interest rates

\begin{tabular}{|l|c|c|c|c|c|c|}
\hline & \multicolumn{3}{|c|}{ Average 1991-1995 } & \multicolumn{2}{c|}{ Average during Sample Period } \\
M2/GDP & $\begin{array}{c}\text { Annual } \\
\text { Growth } \\
\text { Real GDP } \\
\text { (percent) }\end{array}$ & $\begin{array}{c}\text { Real } \\
\text { interest rate } \\
\text { (percent) }\end{array}$ & M2/GP & $\begin{array}{c}\text { Annual } \\
\text { Growth } \\
\text { Real GDP } \\
\text { (percent) }\end{array}$ & $\begin{array}{c}\text { Real } \\
\text { Interest rate } \\
\text { (percent) }\end{array}$ \\
\hline Ghana & 0.11 & 4.5 & 2.1 & 0.11 & 4.7 & 10.6 \\
Côte d'Ivoire & 0.16 & 7.1 & 0.6 & 0.17 & 8.6 & -11.4 \\
Burundi & 0.11 & 3.6 & -1.0 & 0.12 & 2.3 & 8.0 \\
Zimbabwe & 0.13 & 0.9 & -1.4 & 0.12 & -0.3 & -1.2 \\
Kenya & 0.16 & 1.6 & -0.1 & 0.17 & 0.7 & -4.9 \\
Cameroon & 0.10 & -1.9 & 0.9 & 0.09 & -0.8 & -6.0 \\
\hline
\end{tabular}

Source: International Financial Statistics, IMF. Real interest rates are calculated using the discount rate at the central bank minus the inflation rate in the period.

In this paper, we will focus on data on credit market participation, more particularly on demand for and access to credit, from the point of view of firms in the manufacturing sector. We do not have access to data to model in detail bank policy nor loan performance. In the survey, questions were asked about whether firms applied for loans, if not, why not and if they applied whether applications were approved $^{8}$. Also, details on recent lending experiences are available as well.

Table 2 gives an overview of some of the firms' involvement in credit markets and other characteristics. First, we notice that in most countries, the percentage of firms receiving loans is very small. Formal sector debt as a percentage of capital is also relatively low ${ }^{9}$. Most lending is collateralised, with few differences across countries. Most non-collateralised loans appear to have alternative guarantees and conditions attached. The value of collateral is typically high: in all countries it is on average higher than the value of the loan (on average more than twice).

\footnotetext{
${ }^{8}$ The survey also included several questions asking the subjective perception of the manager of the major problems for the firm, including for firm expansion. The respondent could identify finance as a constraint and assign ordinal intensities. In general, a lot of complaints were found - in most countries lack of credit was the most single important complaint. However, this sort of question has to be treated with caution because the respondent may well hope that participation in a world bank survey may carry prospects of easy financing and so the shrewd response is to declare a need for more capital.

${ }^{9}$ The capital definition used in this paper is the replacement value of plant and equipment. In some cases, sales values are used when replacement values are missing.
} 
Many more firms obtain overdrafts than loans. The number of overdrafts is especially high in Kenya and Zimbabwe: 60 percent or more of the firms have one. However, the use of overdrafts appears to be very different in both countries: in Kenya, overdrafts are reportedly regularly used to finance investment, but in Zimbabwe, banks are known to scrutinise carefully firm accounts to ensure that no hard core debt develops in this way (Biggs and Srivastava (1997)). The Cameroon and Kenya micro-evidence is consistent with the perceived crisis in the banking system, with high debts presumably linked to bad loans for parts of the economy. Alternative sources of credit are limited. Informal sector borrowing, while not uncommon, remains low in all countries considered. Only in Ghana, where formal credit and especially overdrafts seem rare, informal loans are more common ${ }^{10}$. Nevertheless, informal credit markets are relatively unimportant for the manufacturing sector in these economies. The survey also found that ROSCAs were irrelevant and virtually absent in most countries except for Cameroon (Biggs and Srivastava (1997)).

We also report on likely reasons for credit market participation. Just under half the firms report to have invested in plant and equipment in the last year. Still, the investment rates (relative to capital) are very low at on average only about 12 percent $^{11}$. Note also that Cameroon, the country with the highest percentage of firms receiving credit and high debt relative to capital, has the lowest proportion of firms investing. This suggests that credit demand in Cameroon is not mainly related to investment demand.

Working capital needs may be another reason for high credit demand. We use the total costs (material inputs and other costs) plus the wage bill as a proxy of the cash flow needed, relative to the capital stock. Côte d'Ivoire has the highest ratio, consistent with the fact that they are using most overdrafts relative to capital. Note finally that trade credit (from suppliers) provides an important means of financing working capital. A large number of firms are involved in receiving trade credit, with the highest involvement in Zimbabwe and the lowest in Burundi. For most firms, it provides the single most important source of working capital financing, with 62 percent of firms receiving some at the time of the survey. Relative to capital, it is very significant, and well above the value of overdraft facilities received ${ }^{12}$. Trade credit is analysed in detail by Cuevas et al. (1993), Fisman (1998), Fafchamps et al. (1995) and Fafchamps $(1997,2000)$ and is not discussed further in this paper.

\footnotetext{
${ }^{10}$ As will become clear below, this is mainly related to the relatively small size of the average firm in the Ghanaian sample.

${ }^{11}$ Only in Burundi was investment larger, although the reason appears mainly that we are dealing with a sample with relatively larger firms.

${ }^{12}$ Note that the data reported only include trade credit received, not trade credit given to e.g. customers, which would reduce the net rates considerably.
} 
Table 2 Firm characteristics and credit markets

\begin{tabular}{|l|c|c|c|c|c|c|c|}
\hline & Burundi & $\begin{array}{c}\text { Came- } \\
\text { roon }\end{array}$ & $\begin{array}{c}\text { Côte } \\
\text { d'Ivoire }\end{array}$ & Ghana & Kenya & $\begin{array}{c}\text { Zimba- } \\
\text { bwe }\end{array}$ & $\begin{array}{c}\text { All } \\
\text { sample }\end{array}$ \\
\hline Received loan in last year? & 0.14 & 0.08 & 0.09 & 0.06 & 0.11 & 0.15 & 0.10 \\
Debt to banks as \% of capital & 0.12 & 0.19 & 0.06 & 0.03 & 0.11 & 0.19 & 0.12 \\
\% firms with overdraft facility & 0.42 & 0.44 & 0.43 & 0.24 & 0.60 & 0.66 & 0.48 \\
Overdraft as \% of capital & 0.07 & 0.14 & 0.19 & 0.05 & 0.15 & 0.17 & 0.14 \\
& & & & & & & \\
\% firms with informal sector debts & 0.10 & 0.16 & 0.04 & 0.22 & 0.09 & 0.14 & 0.13 \\
Informal debt as \% total capital & 0.08 & 0.04 & 0.08 & 0.11 & 0.02 & 0.05 & 0.06 \\
& & & & & & & \\
\% firms currently receiving trade credit & 0.44 & 0.62 & 0.55 & 0.46 & 0.62 & 0.81 & 0.62 \\
Trade credit outstanding as \% capital & 0.07 & 0.26 & 0.34 & 0.21 & 0.29 & 0.26 & 0.27 \\
\% firms providing collateral (formal & 0.79 & 0.77 & 0.69 & 0.69 & 0.91 & 0.75 & 0.78 \\
loans) & & & & & & & \\
Collateral value to loan size ratio & 1.66 & 1.22 & 1.63 & 2.39 & 2.48 & 2.01 & 2.13 \\
\% firms invested in last year & & & & & & & \\
Investment as \% of capital & 0.46 & 0.25 & 0.50 & 0.45 & 0.43 & 0.69 & 0.46 \\
Costs as \% capital & 0.24 & 0.10 & 0.11 & 0.11 & 0.10 & 0.11 & 0.12 \\
\hline Observations & 3.08 & 1.98 & 4.28 & 3.45 & 2.14 & 2.47 & 2.70 \\
\hline
\end{tabular}

Pooled sample over time and countries (2780 firms). Collateral data for those firms reporting details.

In short, these data suggest that financial market involvement, especially in the form of borrowing, is limited, but there are differences across countries. There are also important differences with respect to the size of the firms. Table 3 gives the same characteristics by firm size, based on the number of employees. The differences are striking. Large firms receive more loans and have, relative to capital, a higher indebtedness. They have far more access to overdraft facilities. They rely less on informal credit, but even micro and small firms have relatively low informal debt relative to capital. Trade credit is more important for all firm groups, but even here, large firms have far more access. About 90 percent of the large firms have outstanding debts to suppliers. Large firms invest far more, even though the amounts involved relative to capital remain modest on average. Small firms appear to have more need of working capital relative to capital, probably linked to undercapitalisation of their activities. Finally, the use and relative value of collateral is not different for large or smaller firms.

Small firms have less credit, but does this mean they are constrained in the credit market? We define firms as "unconstrained" in the credit market if they state that they do not wish to obtain external funds (i.e. no credit demand) or that they were able to obtain a loan. Those that applied and were refused, and those that did not apply because they expected to be refused, are considered "constrained". Note that this definition is one of potential "loan rationing", i.e. we identify whether a firm that would have liked a loan could not get one (type II rationing). We cannot account for cases of "size rationing" (type I rationing), in which firms borrow less than desired or for firms that are facing higher interest rate costs, due to monitoring costs imposed following the credit market informational asymmetries. In short, a strict definition of credit constraints is used. In the following tables, the data underlying these choices are summarised, using pooled data over three rounds. 
Table 3 Credit market participation and firm size (by employees)

\begin{tabular}{|l|c|c|c|c|c|}
\hline & $\begin{array}{c}\text { Micro } \\
(1-5)\end{array}$ & $\begin{array}{c}\text { Small } \\
(6-25)\end{array}$ & $\begin{array}{c}\text { Medium } \\
(26-100)\end{array}$ & $\begin{array}{c}\text { Large } \\
(100+)\end{array}$ & $\begin{array}{c}\text { All } \\
\text { sample }\end{array}$ \\
\hline Received loan in last year? & 0.02 & 0.07 & 0.11 & 0.21 & 0.10 \\
Debt to banks as \% of capital & 0.07 & 0.11 & 0.14 & 0.18 & 0.12 \\
\% firms with overdraft facility & 0.10 & 0.30 & 0.64 & 0.86 & 0.47 \\
Overdraft as \% of capital & 0.06 & 0.09 & 0.16 & 0.25 & 0.14 \\
\% firms with informal sector debts & 0.16 & 0.16 & 0.09 & 0.09 & 0.13 \\
Informal debt as \% total capital & 0.07 & 0.09 & 0.02 & 0.04 & 0.06 \\
& & & & & \\
\% firms currently receiving trade credit & 0.32 & 0.53 & 0.70 & 0.90 & 0.62 \\
Trade credit outstanding as \% capital & 0.15 & 0.23 & 0.33 & 0.35 & 0.27 \\
& & & & & \\
\% firms providing collateral (formal loans) & 0.73 & 0.78 & 0.81 & 0.77 & 0.78 \\
Collateral value to loan size ratio & 1.82 & 2.48 & 1.92 & 2.18 & 2.13 \\
& & & & & \\
\% firms invested in last year & 0.33 & 0.38 & 0.45 & 0.71 & 0.46 \\
Investment as \% of capital & 0.09 & 0.10 & 0.07 & 0.09 & 0.12 \\
Costs as \% capital & 3.89 & 3.14 & 2.21 & 1.90 & 2.70 \\
\hline Observations & 645 & 330 & 546 & 510 & 2031 \\
\hline
\end{tabular}

Pooled sample across countries and time.

Table 4 gives the distribution of firms applying for loans in the previous year across countries. In table 5, the distribution is given for different size groups. There seem to be some differences across countries, but overall a large amount did not apply for loans. From those applying, the majority of firms obtain loans ${ }^{13}$. Overall, about a fifth of firms applied for loans, with just under 60 percent obtaining them. Across the size distribution, the differences are large with much fewer applications and a smaller success rate among the smaller firms.

Table $4 \quad$ Formal credit market participation by Country (percentages)

\begin{tabular}{|l|c|c|c|c|c|c|c|}
\hline & Burundi & $\begin{array}{c}\text { Came- } \\
\text { roon }\end{array}$ & $\begin{array}{c}\text { Côte } \\
\text { d'Ivoire }\end{array}$ & Ghana & Kenya & $\begin{array}{c}\text { Zimba- } \\
\text { bwe }\end{array}$ & $\begin{array}{c}\text { All } \\
\text { sample }\end{array}$ \\
\hline did not apply for a loan & 77 & 80 & 84 & 86 & 82 & 79 & 82 \\
applied and did not receive & 9 & 12 & 7 & 8 & 6 & 6 & 8 \\
applied and received a loan & 14 & 8 & 9 & 6 & 11 & 15 & 10 \\
\hline
\end{tabular}

Table $5 \quad$ Formal credit market participation by Firm Size (percentages of firms)

\begin{tabular}{|l|c|c|c|c|c|}
\hline & $\begin{array}{c}\text { Micro } \\
(1-5)\end{array}$ & $\begin{array}{c}\text { Small } \\
(6-25)\end{array}$ & $\begin{array}{c}\text { medium } \\
(26-100)\end{array}$ & $\begin{array}{c}\text { large } \\
(100+)\end{array}$ & all \\
\hline did not apply & 92 & 82 & 80 & 75 & 82 \\
applied and did not receive & 6 & 11 & 9 & 5 & 8 \\
applied and received & 2 & 7 & 11 & 20 & 10 \\
\hline
\end{tabular}

The large number of firms not applying does not mean that they are not credit constrained, since they may not want to incur the transactions if they suspect they will not obtain any loans. In table 6 , the reasons are given why they did not apply for a loan in the last year by country and in table 7 by firm size. It seems that about 34 percent

\footnotetext{
${ }^{13}$ For a small number of loan applications, no decision had been reached at the time of the survey. These observations were dropped from the data.
} 
of firms reported that they did not apply because they did not need one and another 14 percent did not want to incur debt or had already too much debt. But quite a few firms gave reasons more closely related to being constrained: 12 percent reported not to apply because did not think they would get one, 9 percent did not have sufficient collateral and 8 percent found the process too difficult. High interest rates were quoted by 9 percent of firms.

There are important differences in these reasons across the size distribution: very few large firms reported that they did not apply because they thought they would not get a loan, while it is the main reason why the smallest firms did not apply. Collateral is similarly rarely cited as a reason by large firms. Large firms mainly report that they did not want loans as a reason for not applying. Debt and difficulties with the application process are relatively more important for the smaller firms.

Table 6 Why did firms not apply for loans? By country. (percentages of firms)

\begin{tabular}{|l|c|c|c|c|c|c|c|}
\hline & Cameroon & $\begin{array}{l}\text { Cote } \\
\text { d'ivoire }\end{array}$ & Ghana & Kenya & $\begin{array}{l}\text { Zimba- } \\
\text { bwe }\end{array}$ & Burundi & All \\
\hline Inadequate collateral (C) & 13 & 7 & 12 & 8 & 8 & 3 & 9 \\
don't want to incur debt (NC) & 11 & 5 & 10 & 10 & 9 & 10 & 9 \\
Process too difficult (C) & 6 & 7 & 12 & 7 & 7 & 1 & 8 \\
didn't need one (NC) & 34 & 26 & 29 & 29 & 51 & 49 & 34 \\
didn't think I'd get one (C) & 11 & 25 & 10 & 13 & 4 & 7 & 12 \\
Interest rate too high (NC) & 8 & 16 & 6 & 5 & 10 & 16 & 9 \\
Already heavily indebted & 9 & 5 & 2 & 4 & 4 & 1 & 5 \\
(NC) & 8 & 8 & 19 & 26 & 8 & 12 & 15 \\
Other & 100 & 100 & 100 & 100 & 100 & 100 & 100 \\
\hline Total & & & & & & \\
\hline
\end{tabular}

$\mathrm{C}=$ constrained; $\mathrm{NC}=$ not constrained

Table $7 \quad$ Why did firms not apply for loans? By firm size (percentages of firms).

\begin{tabular}{|l|c|c|c|c|c|}
\hline & $\begin{array}{c}\text { Micro } \\
(1-5)\end{array}$ & $\begin{array}{c}\text { Small } \\
(6-25)\end{array}$ & $\begin{array}{c}\text { Medium } \\
(26-100)\end{array}$ & $\begin{array}{c}\text { Large } \\
(100+)\end{array}$ & All \\
\hline Inadequate collateral (C) & 15 & 10 & 3 & 2 & 9 \\
don't want debt (NC) & 9 & 11 & 9 & 5 & 9 \\
Process too difficult (C) & 13 & 8 & 4 & 1 & 8 \\
didn't need one (NC) & 15 & 29 & 50 & 60 & 34 \\
didn't think I'd get one (C) & 23 & 14 & 6 & 3 & 12 \\
Interest rate too high (NC) & 4 & 12 & 14 & 11 & 9 \\
Already heavily indebted (NC) & 1 & 3 & 4 & 5 & 5 \\
Other & 20 & 13 & 10 & 13 & 15 \\
\hline
\end{tabular}

It is possible to interpret these answers in terms of the existence of credit constraints. Some firms appear not to be interested in credit: they do not want a loan or do not find it in their interest to incur more or any debt. Others are clearly providing answers suggesting credit market constraints: those who do not have enough collateral, for whom the process is too difficult and others who think they will be refused a loan even if they are willing to pay current interest rates. These firms will be considered in 
the "constrained" group ${ }^{14}$. One group is more problematic: those who report that high interest rates are the reason for not applying. It suggests that they are not willing to pay current prices, so that they can hardly be considered rationed. Nevertheless, they could be facing the increasing part of the supply curve due to monitoring cost, making credit too expensive for them. In this case they are indeed suffering the consequences of the market imperfections. Since we aim to focus more on rationed groups at given interest rates, we include the group reporting high interest rates as the reason for not applying, as belonging to the "unconstrained, no credit demand" group. To this group we also add those firms which do not want to borrow because they do not need them or do not want to have (more) debt.

Combining this information with the information contained in table 4 and 5, we can allocate all firms in three groups: those "unconstrained without credit demand", those "constrained" defined as before, adding those rejected after applying for a loan and finally an "unconstrained with credit demand" group who obtained loans. Tables 8 and 9 provide the frequencies of firms in these groups by firm size and by country.

Table 8 Credit constraints by Firm Size

\begin{tabular}{|l|c|c|c|c|c|}
\hline & Micro & Small & Medium & Large & All \\
\hline no credit demand & 33 & 50 & 67 & 66 & 55 \\
demand, but rejected * & 64 & 42 & 21 & 10 & 33 \\
received loan & 3 & 8 & 12 & 23 & 12 \\
\hline
\end{tabular}

*includes firms that suggested that a loan application would be rejected by banks

Table 9 Credit constraints by country

\begin{tabular}{|l|c|c|c|c|c|c|c|}
\hline & Burundi & Cameroon & $\begin{array}{c}\text { Cote } \\
\text { d'Ivoire }\end{array}$ & Ghana & Kenya & Zimbabwe & All \\
\hline no credit demand & 51 & 44 & 47 & 52 & 64 & 67 & 55 \\
demand, but rejected * & 34 & 47 & 42 & 40 & 24 & 17 & 33 \\
received loan & 15 & 9 & 11 & 8 & 12 & 16 & 12 \\
\hline
\end{tabular}

*includes firms that suggested that a loan application would be rejected by banks

As can be seen, a large proportion of firms - on average more than half - do not have any credit demand. About a third either applied and were rejected for loans, or did not apply expecting to be rejected, and can be considered constrained. Across the size distribution, the differences appear quite large. Close to two-thirds of the micro firms appear constrained, while this is only 10 percent for the large firms. A large number of large firms - about two-thirds - simply do not participate in the credit market because they do not want to, compared to only a third of the micro firms. Very few microfirms apply for loans but this cannot be interpreted as meaning that they do not have a demand for external funds. As most firms in Africa are micro and small firms, the evidence suggests that most are credit constrained.

\footnotetext{
${ }^{14}$ Note that this classification is consistent with the theoretical discussion: firms have a demand for outside funds, but are not willing or able to apply because of the collateral constraint, perceived low success rates and high transactions costs. Note also that those applying but whose application was rejected would be firms which found it in their interest to apply (and incur costs) given the perceived success rate. Applications are still risky and those firms with rejected applications faced the 'bad' expost outcome.
} 


\section{Econometric model}

In the econometric analysis, we investigate the factors determining whether firms have a demand for external funds and whether it is satisfied. We investigate the screening applied by banks and we examine why particular firms appear to be constrained. In line with the theoretical model, we consider a decision process in two stages. First, the firm decides whether it has a demand for external financing. In a second stage, we ask whether for those firms with a demand for external financing, there is a matching supply of credit by financial sector. The first stage involves an analysis on the entire sample; the second stage involves only those with a demand for credit $^{15}$.

Given the data, for both stages in the credit allocation process, the depedent variable is binary, so we use a probit model. In principle, the choices are interlinked, while the second stage is only observed for certain outcomes in the first stage. Defining $y_{i 1}=1$ if credit demand is satisfied and $\mathrm{y}_{\mathrm{i} 2}=1$ if the firm has a demand for external finance, the model becomes:

$$
\begin{gathered}
z_{i 1}=\beta_{1} x_{i 1}+e_{i 1} ; y_{i 1}=1 \text { if } z_{i 1}>0, y_{i 1}=0 \text { otherwise } \\
z_{i 2}=\beta_{2} x_{2}+e_{i 2} ; y_{i 2}=1 \text { if } z_{i 2}>0, y_{i 2}=0 \text { otherwise } \\
y_{i 1} \text { is observed only when } y_{i 2}=1
\end{gathered}
$$

Since it is quite likely that the errors in both stages are correlated, estimating the first equation (i.e. the second stage) while ignoring the information from the first stage (i.e. the selection process) would result in a sample selection bias. To estimate this model we can use a bivariate probit model with sample selection (or a Heckman probit), in which both the selection equation as the second stage equation are a probit model. Both stages are jointly estimated using maximum likelihood or using two-stage methods. In particular, it is assumed that $\left(\mathrm{e}_{\mathrm{i} 1}, \mathrm{e}_{\mathrm{i} 2}\right)$ are bivariate normally distributed with $\mathrm{E}\left(\mathrm{e}_{\mathrm{i} 1}\right)=\mathrm{E}\left(\mathrm{e}_{\mathrm{i} 2}\right)=0, \operatorname{Var}\left(\mathrm{e}_{\mathrm{i} 1}\right)=\operatorname{Var}\left(\mathrm{e}_{\mathrm{i} 2}\right)=1$ and $\operatorname{Cov}\left(\mathrm{e}_{\mathrm{i} 1}, \mathrm{e}_{\mathrm{i} 2}\right)=\rho$ (details are in Greene, 1993, p.660-664).

When running this regression on the data at hand, we may ignore the possible implications of the panel structure of the data. In particular, we assume that the errors are uncorrelated over time, despite the fact that observations are from the same firms. The panel nature would suggest that heterogeneity in present in the data and depending on the form of heterogeneity, causing inefficiency and even inconsistency of the estimators. In general, the first equation (and similarly the second) in (12) can be written as follows:

$$
z_{i 1 t}=\alpha_{i}+\beta_{1} x_{i 1 t}+e_{i 1 t} ; y_{i 1 t}=1 \text { if } z_{i 1 t}>0, y_{i 1 t}=0 \text { otherwise }
$$

Since the data are a sample of firms from a large population, it is reasonable to treat $\alpha_{i}$ as random effects and more efficient estimators could be obtained by assuming that they are drawn from a time-invariant distribution. Below we report the random effects

\footnotetext{
${ }^{15}$ As in the previous section, we assume that those firms actually applying for loans and those not applying but suggesting they would have liked to can be considered together in the analysis of whether credit demand was satisfied. In appendix 3 we present a test on whether this is valid.
} 
estimator for each of the equations in (12). However, the random effects model assumes that the individual effects are uncorrelated with the explanatory variables. This may be a strong assumption. For example, the heterogeneity may be reflecting unobserved differences in characteristics correlated with firm size or with outstanding debts. Standard or random effects probit estimators would result in inconsistent estimates. We therefore also report fixed effects estimates for the model.

Implementing these panel data estimators on (12) is not self-evident. First, fixed effects probit models are not feasible (Greene, 1993, p. 655). Instead, Chamberlain's conditional maximum likelihood estimator for the panel logit model, effectively a fixed effects estimator, will be reported. A random effects probit model is reported as well. Using these panel data techniques, a bivariate sample selection model similar to (12) is not straightforward either (Maddala (1987)). Fixed and random effects estimates are therefore only reported for each of the stages separately. A final practical problem is that the fixed effects model effectively only uses firms shifting status during the panel period with respect to credit demand and constraints. Over this short panel, only a relatively limited number of firms do this, limiting the degrees of freedom considerably. As a consequence, these results have to be treated with considerable caution. Nevertheless, they can give some indication on whether the other results are seriously affected by firm heterogeneity correlated with other variables in the model. Furthermore, one of crucial variables of interest - firm size does not change very much over a short panel, so that the fixed effects estimators may not give much information on the relevance or existence of a 'true' size effect, controlling for fixed heterogeneity.

In terms of explanatory variables, the factors determining the demand for credit include those determining whether firms want to expand their activities. As discussed in section 2, without credit market imperfections, only shocks to the conditions faced by the firm in the economy should matter for investment. To proxy those shocks, we use time, sector and country dummies. To allow for adjustment costs and past constraints in financing investment, we include a measure of desired capital, based on Caballero, Engel and Haltiwanger (1995). Appendix 2 gives the details. Working capital needs will be proxied by measures of liquidity: profit rates, alternative sources of funds, such as informal credit, outstanding formal debt and access to overdraft financing. These factors will also determine the demand for external funds relative to internal sources for financing investment. Other controls for transactions and opportunity costs of funds are variables describing the legal status (limited liability, personal firm, co-operative, state firm etc.) and ownership structure (the relative importance of state, domestic and foreign ownership). Firm characteristics, such as whether the firm owns other business, characteristics and assets of the owner, firm age, whether it keeps accounts, etc. are also included to control for heterogeneity in credit demand. They can be seen as proxies for transactions costs in applying for loans, access to different sources of collateral and alternative sources of finance. Finally, dummies describing the size of the firm are entered as well, effectively asking whether the other characteristics included sufficiently proxy for heterogeneity correlated to firm size.

Firms that have a demand for external credit may either receive a loan or stay frustrated (either by being refused or by expecting to be refused a loan). In principle, 
banks would like to use similarly extensive information to allocate credit as used by firms to decide about their demand for external finance, since these factors will affect the likelihood of repayment, agency and enforcement problems, or in short, the creditworthiness of the firm. However, it is unlikely that banks can use the full information set used by firms. Even if the firm has accounts, banks are unlikely to have up-to-date and complete information on issues such as profitability, desired capital stock, access to informal and other sources of credit, etc. and other current firm-specific characteristics. We will assume that banks use sector-specific predictions of profitability for each firm, based on sector, country, time, ownership, legal status and other easily observable characteristics. We assume that the banks have access to information on the current formal debt position and on the capital of the firm, which they can use to assess its current net worth and the ability to provide collateral for loans. We use the debt-capital ratio and expect that higher rates would reduce the willingness of the financial sector to satisfy the demand for credit of the firms, since the risk of bankruptcy may be higher. If factors such as predicted profitability or debt ratios dominate the allocation of credit, then one can hardly speak of credit constraints; rather, banks are screening good debts from bad debts.

Agency and enforcement problems are other reasons for credit to be refused and a cause of market imperfections. Ownership structure and the legal status of firms is bound to affect the banks' monitoring costs; they definitely will affect the enforcement possibilities. We also include controls for whether firm keeps accounts, firm age, characteristics and assets of the owner. They could facilitate monitoring or provide collateral substitutes. Note that rationing on the part of banks may well be consistent with profit maximising behaviour on the part of banks. While there is a credit market failure, this does not necessarily mean an unreasonable bias by banks against certain types of firms. If, however, controlling for monitoring and transactions costs, banks reject loans to at least as profitable firms as those receiving loans, then the rationing scheme applied may not be consistent with profit maximisation.

Finally, this modelling approach implies that identification of the sample selection equation occurs via firm-specific time-varying variables, such as current profitability, desired capital stock, access to alternative funds, etc. In the next section we give the results.

\section{Results}

Table 10 gives the descriptive statistics on the variables used in the regression analysis. The constrained firms typically appear to be more likely to be private firms, with one owner, small in size, younger, not keeping accounts, with owners that do not have other business or assets that could be used for collateral. Firms with no credit demand are somewhat smaller and do not have as much debt compared to those obtaining loans. 
Table 10 Descriptive statistics

\begin{tabular}{|c|c|c|c|}
\hline & no credit demand & $\begin{array}{l}\text { credit demand not } \\
\text { satisfied }\end{array}$ & $\begin{array}{l}\text { credit demand } \\
\text { satisfied }\end{array}$ \\
\hline \multicolumn{4}{|l|}{ Sector } \\
\hline Wood & 0.21 & 0.25 & 0.22 \\
\hline Textile & 0.26 & 0.28 & 0.29 \\
\hline Metal & 0.23 & 0.26 & 0.21 \\
\hline Food & 0.28 & 0.19 & 0.25 \\
\hline \multicolumn{4}{|l|}{ Legal status } \\
\hline Solo firm & 0.26 & 0.50 & 0.17 \\
\hline Partnership & 0.07 & 0.10 & 0.04 \\
\hline Limited liability & 0.50 & 0.25 & 0.57 \\
\hline State corporation & 0.01 & 0.01 & 0.02 \\
\hline Cooperative & 0.01 & 0.02 & 0.03 \\
\hline Subsidiary domestic & 0.02 & 0.01 & 0.04 \\
\hline Subsidiary foreign & 0.03 & 0.00 & 0.02 \\
\hline \multicolumn{4}{|l|}{ Ownership } \\
\hline Private domestic firm & 0.65 & 0.83 & 0.65 \\
\hline Private foreign firm & 0.15 & 0.08 & 0.11 \\
\hline Private domestic \& foreign firm & 0.14 & 0.07 & 0.17 \\
\hline State/private domestic & 0.01 & 0.00 & 0.02 \\
\hline State/private foreign & 0.02 & 0.01 & 0.04 \\
\hline State/private foreign $\&$ dom & 0.01 & 0.00 & 0.01 \\
\hline \multicolumn{4}{|l|}{ Country \& location } \\
\hline Zimbabwe & 0.29 & 0.12 & 0.36 \\
\hline Côte d'Ivoire & 0.08 & 0.12 & 0.09 \\
\hline Cameroon & 0.14 & 0.27 & 0.16 \\
\hline Kenya & 0.30 & 0.18 & 0.24 \\
\hline Ghana & 0.17 & 0.28 & 0.13 \\
\hline Burundi & 0.03 & 0.03 & 0.02 \\
\hline Firm in capital city? & 0.68 & 0.66 & 0.77 \\
\hline
\end{tabular}

\begin{tabular}{|c|c|c|c|}
\hline \multicolumn{4}{|l|}{ Firm characteristics } \\
\hline Formal debt/capital $^{\mathrm{a}}$ & 0.09 & 0.07 & 0.24 \\
\hline Informal debt/capital & 0.03 & 0.05 & 0.02 \\
\hline Overdraft/capital & 0.14 & 0.09 & 0.16 \\
\hline Access to overdraft? & 0.64 & 0.26 & 0.78 \\
\hline Profit/capital ratio & 0.72 & 0.86 & 0.77 \\
\hline Predicted profit/capital ratio ${ }^{b}$ & 0.73 & 0.88 & 0.72 \\
\hline Mandated investment ${ }^{\mathrm{c}}$ & 0.06 & 0.00 & 0.12 \\
\hline Mandated investment-alternative ${ }^{\mathrm{d}}$ & 0.16 & 0.19 & 0.21 \\
\hline Micro firm & 0.08 & 0.27 & 0.01 \\
\hline Small firm & 0.27 & 0.44 & 0.21 \\
\hline Medium firm & 0.35 & 0.20 & 0.27 \\
\hline Large firm & 0.30 & 0.09 & 0.50 \\
\hline Employment level & 153 & 53 & 292 \\
\hline Firm age & 19.8 & 11.8 & 19.5 \\
\hline Accounts? & 0.88 & 0.57 & 0.94 \\
\hline Firms with owner characteristics ${ }^{e}$ & 0.71 & 0.85 & 0.68 \\
\hline Age owner & 45.9 & 42.1 & 46.4 \\
\hline Born in this town? & 0.81 & 0.83 & 0.85 \\
\hline Time spent in this town & 23.2 & 21.4 & 24.6 \\
\hline own other business? & 0.36 & 0.28 & 0.47 \\
\hline sex owner & 0.95 & 0.97 & 0.99 \\
\hline
\end{tabular}




\begin{tabular}{|l|l|l|l|}
\hline other business in sector & 0.18 & 0.18 & 0.24 \\
own house,vehicle, farm? & 0.68 & 0.54 & 0.67 \\
Number of observations (full & 770 & 390 & 161 \\
information for regressions, & & & \\
including panel data for desired & & & \\
capital) & & & \\
\hline
\end{tabular}

${ }^{\text {a}}$ Formal outstanding debt, excluding loans received in the current year.

${ }^{\mathrm{b}}$ Predicted profit rate, using information on sector, country, location, ownership, firm size and legal status. Country dummies interacted with time dummies. See table A.2 in appendix 4.

${ }^{\mathrm{c}}$ Mandated investment, using calculated capital before investment in current period.

${ }^{\mathrm{d}}$ Mandated investment, alternative measures, using lagged capital. Details in appendix 2.

${ }^{\mathrm{e}}$ Detailed survey questions on the (main) owners of firms were taken for private domestic firms, provided they were available for interview. For cooperatives, the chairman of the cooperative was interviewed. Subsequently, we will refer to them as 'privately owned firms'.

Table 11 gives the results of the estimation using the bivariate probit model with sample selection. We give the results for all firms, as well as for firms with an identifiable private owner, about whom we have further information ${ }^{16}$. First, looking at the demand for credit, we find that co-operatives are more likely to have a demand for external finance (by 36 percent) and that firms with some foreign ownership have lower demand (17 percent less likely relative to private domestic firms), presumably reflecting access to other sources of finance. Access to overdrafts also reduces the demand for credit, while high indebtness (measured as outstanding debt excluding any loans obtained in the current year) makes a firm more likely to have currently a demand for external finance. The squared term is negative, but the overall effect only starts becoming negative at a ratio with debts 66 percent above total capital. Evaluated at the mean, a doubling of the ratio of debt relative to capital at the beginning of the period increases the demand for loans by 13 percent. As expected, younger firms also are more likely to demand external finance. For privately owned firms, we find broadly speaking the same effects, with additionally a positive effect on the demand for external finance when the owner owns other business as well. Note that 'medium' sized firms - between 26 and 100 employees - are less likely to have a demand for credit than micro, small as well as large firms (i.e. a 10 percentage points lower probability). The coefficients on micro and small firms are not significantly different from zero. In other words, controlling for a series of characteristics typically correlated with small or micro firms, such as keeping accounts, access to other sources of finance and ownership structure, the demand for credit is not significantly different for large and small or micro firms. If we observe differences in credit allocation between small and large firms, then differences in demand will not be able to explain them.

Turning to the issue of whether demand is satisfied, we notice some interesting effects. First, firms with high expected profits are more likely to get credit than other firms - consistent with banks screening applications to obtain a portfolio of profitable ventures. In particular, evaluated at mean characteristics, doubling the expected profitability ratio increases the probability that a firm will get a loan by about 27 percent ${ }^{17}$. Secondly, we find very strong and significant firm size effects. Relative to

\footnotetext{
${ }^{16}$ Selected marginal effects were calculated and reported in the text.

${ }^{17}$ Note that the reported marginal effects are conditional on expressing a demand for loans.
} 
large firms, micro firms have 31 percent less chance of having credit demand satisfied, while this is respectively 20 and 13 percent lower for small and medium firms. Note that this effect exists despite controls for whether firms have accounts and for characteristics of the owner, such as assets and ownership of other business interests. In other words, the size effects must reflect the role of other characteristics correlated with size, beyond these included in the regression. Thirdly, we also note a strong and positive effect of outstanding debt, although the square is negative again. We would have expected an overall negative effect, especially at high values of debt over capital - highly indebted firms are likely to be quite risky to give additional loans to. For most reasonable values, we find a positive effect: the overall effect becomes negative for a debt-capital ratio of 1.76. Evaluated at the mean, a doubling of the debt over capital ratio increases the probability of having its credit demand satisfied by 13 percent for all firms. We find a similar effect for privately owned firms only. To conclude, credit allocation is at least to some extent focused on more profitable firms and sectors. However, small and micro firms face a bias in credit allocation, not explained by obvious transactions costs characteristics, such as whether firms keep accounts or the lack of assets that may be used as collateral. In fact, we observe hysteresis in credit market relationships: banks appear to favour relationships with certain clients who have already substantial debt outstanding, even if these firms may well have a higher risk of default.

These regressions ignore the panel dimension of the data. At least, by not taking into account heterogeneity, the estimates may be inefficient. Random effects estimators are reported in table 12 . Generally speaking, the estimated coefficients and the implied marginal effects are very similar. Medium sized firms, foreign or younger firms and those with overdrafts are less likely to have a demand for credit, while highly indebted firms are more likely to do so. Privately owned firms with male owners or with an owner having other businesses are also more likely to have a demand for external finance. Credit allocation by banks is influenced by profitability considerations, but the positive effect of outstanding debt and the clear additional negative effect of being a small firm remain as well. The size effects is present after controlling for and finding significant effects on other variables that may allow better monitoring by banks, such as accounts, being based in the capital city and firms with overdraft facilities. 
Table $11 \quad$ Sample selection model

\begin{tabular}{|c|c|c|c|c|c|c|c|c|}
\hline & \multicolumn{4}{|c|}{ Demand? (probit - selection equation) } & \multicolumn{4}{|c|}{ Demand satisfied? (2 ${ }^{\text {nd }}$ stage probit) } \\
\hline & \multicolumn{2}{|c|}{ all firms } & \multicolumn{2}{|c|}{$\begin{array}{l}\text { Firms with owner } \\
\text { characteristics }\end{array}$} & \multicolumn{2}{|c|}{ all firms } & \multicolumn{2}{|c|}{$\begin{array}{l}\text { Firms with owner } \\
\text { characteristics }\end{array}$} \\
\hline & coeff & z-value & coeff & z-value & coeff & z-value & coeff & z-value \\
\hline Solo firm & -0.01 & -0.12 & -0.03 & -0.24 & -0.06 & -0.27 & -0.10 & -0.43 \\
\hline Partnership & 0.14 & 0.92 & -0.03 & -0.18 & -0.36 & -1.24 & -0.45 & -1.46 \\
\hline State corporation & 0.26 & 0.75 & & & 0.12 & 0.23 & & \\
\hline Cooperative & 0.95 & $2.47 * *$ & 1.11 & $2.37 *$ & 0.98 & $2.01 *$ & 0.90 & 1.39 \\
\hline Subsidiary domestic & 0.15 & 0.56 & -0.14 & -0.21 & 0.07 & 0.17 & & \\
\hline Subsidiary foreign & -0.18 & -0.52 & & & 3.07 & 0.01 & & \\
\hline Private foreign firm & -0.50 & $-3.70 * *$ & -0.52 & $-2.97 * *$ & -0.05 & -0.20 & 0.11 & 0.28 \\
\hline Private domestic/foreign & -0.23 & $-1.83+$ & -0.25 & -1.46 & -0.05 & -0.21 & -0.24 & -0.79 \\
\hline State/private domestic & -0.33 & -0.84 & & & 1.48 & 1.54 & & \\
\hline State/private foreign & -0.27 & -0.95 & & & 0.46 & 0.85 & & \\
\hline State/private foreign/domestic & -0.29 & -0.61 & & & 3.73 & 0.01 & & \\
\hline Formal debt/capital & 0.83 & $3.32 * *$ & 0.63 & $2.14 *$ & 1.44 & $3.97 * *$ & 1.66 & 3.81 ** \\
\hline Formal debt/capital squared & -0.25 & $-2.15 *$ & -0.13 & -1.04 & -0.41 & $-2.74 * *$ & -0.50 & $-2.94 * *$ \\
\hline Overdraft/capital & 0.06 & 0.79 & 0.04 & 0.52 & -0.30 & -1.40 & -0.17 & -0.76 \\
\hline Access to overdraft? & -0.21 & $-2.04 *$ & -0.18 & -1.51 & 0.53 & $2.59 * *$ & 0.61 & $2.42 *$ \\
\hline Pred. profit/capital ratio & & & & & 0.95 & $2.30 *$ & 1.03 & $2.01 *$ \\
\hline Micro firm & 0.13 & 0.70 & 0.18 & 0.87 & -2.06 & $-3.69 * *$ & -1.96 & $-3.03 * *$ \\
\hline Small firm & -0.07 & -0.53 & -0.07 & -0.39 & -0.73 & $-2.89 * *$ & -0.75 & $-2.25^{*}$ \\
\hline Medium firm & -0.27 & $-2.38 *$ & -0.26 & $-1.80 *$ & -0.61 & $-3.14 * *$ & -0.58 & $-2.39 *$ \\
\hline Firm age & -0.01 & $-2.53 *$ & -0.01 & $-1.89 *$ & 0.00 & -0.72 & 0.00 & -0.44 \\
\hline Accounts? & -0.42 & $-3.48 * *$ & -0.49 & $-3.72 * *$ & 0.38 & 1.61 & 0.42 & 1.61 \\
\hline Firm in capital city? & -0.01 & -0.10 & -0.11 & -1.05 & 0.24 & 1.38 & 0.28 & 1.33 \\
\hline Cote d'Ivoire & 0.89 & $5.17 * *$ & 0.88 & $3.91 * *$ & -0.98 & -1.62 & -1.51 & $-1.81+$ \\
\hline Cameroon & 0.74 & $5.55 * *$ & 0.88 & $5.24 * *$ & -0.49 & -1.37 & -0.49 & -1.14 \\
\hline Zimbabwe & 0.08 & 0.66 & 0.17 & 1.09 & -0.15 & -0.66 & -0.13 & -0.46 \\
\hline Ghana & 0.31 & $2.50 *$ & 0.43 & $2.54 *$ & -0.27 & -1.05 & -0.44 & -1.17 \\
\hline Burundi & 0.06 & 0.24 & 0.40 & 1.34 & -0.71 & -1.51 & -0.64 & -1.12 \\
\hline Age owner & & & 0.00 & 0.49 & & & -0.01 & -1.06 \\
\hline Born in this town? & & & 0.28 & $2.22 *$ & & & 0.20 & 0.80 \\
\hline Time spent in this town & & & -0.01 & $-1.87+$ & & & 0.00 & 0.33 \\
\hline own other business? & & & 0.25 & $2.42 *$ & & & -0.18 & -0.77 \\
\hline sex owner & & & 0.60 & $2.50 *$ & & & 0.21 & 0.37 \\
\hline Other business in sector? & & & 0.14 & 1.18 & & & 0.20 & 0.99 \\
\hline own house,vehicle, farm? & & & -0.03 & -0.23 & & & -0.14 & -0.66 \\
\hline Informal debt/capital & -0.01 & -0.06 & -0.02 & -0.12 & & & & \\
\hline Profit/capital ratio & 0.00 & -0.14 & 0.02 & 0.51 & & & & \\
\hline Mandated investment & -0.09 & $-1.66+$ & -0.07 & -1.10 & & & & \\
\hline Constant & -0.12 & -0.53 & -0.69 & $-1.70+$ & -1.78 & $-3.57 * *$ & -1.66 & $-1.83+$ \\
\hline Selection term & & & & & 0.83 & 1.61 & 0.96 & 1.42 \\
\hline Number of observations & & 1322 & & 985 & & 551 & & 440 \\
\hline Wald & & $52.39 * *$ & & $49.08 *$ & & & & \\
\hline LR test on selection term & & & & & & 1.58 & & 1.11 \\
\hline
\end{tabular}

Base groups: private domestic firms, firms with limited liability legal status, Kenya, large firms.

Regression controls also for sectors and for year using dummies.

$* *=$ significant at $1 \%$

$*=$ significant at $5 \%$

$+=$ significant at $10 \%$ 
Table 12 Random effects probit model

\begin{tabular}{|c|c|c|c|c|c|c|c|c|}
\hline & \multicolumn{4}{|c|}{ Demand? } & \multicolumn{4}{|c|}{ Demand satisfied? } \\
\hline & \multicolumn{2}{|c|}{ all firms } & \multicolumn{2}{|c|}{$\begin{array}{l}\text { Firms with owner } \\
\text { characteristics }\end{array}$} & \multicolumn{2}{|c|}{ all firms } & \multicolumn{2}{|c|}{$\begin{array}{c}\text { Firms with owner } \\
\text { characteristics }\end{array}$} \\
\hline & Coef. & z-value & Coef. & z-value & Coef. & z-value & Coef. & z-value \\
\hline Solo firm & -0.02 & -0.16 & -0.05 & -0.34 & -0.01 & -0.05 & -0.12 & -0.46 \\
\hline Partnership & 0.12 & 0.55 & -0.08 & -0.37 & -0.50 & -1.28 & -0.48 & -1.29 \\
\hline State corporation & 0.35 & 0.79 & & & -0.06 & -0.08 & & \\
\hline Cooperative & 1.21 & $2.36 *$ & 1.40 & $2.30 *$ & 0.86 & 1.31 & 0.49 & 0.69 \\
\hline Subsidiary domestic & 0.13 & 0.38 & 0.32 & 0.42 & -0.02 & -0.04 & & \\
\hline Subsidiary foreign & -0.22 & -0.50 & & & 0.00 & 0.00 & & \\
\hline Private foreign firm & -0.60 & $-3.42 * *$ & -0.65 & $-2.86 * *$ & 0.31 & 0.89 & 0.45 & 1.06 \\
\hline Private domestic/foreign & -0.29 & $-1.74+$ & -0.34 & -1.57 & 0.11 & 0.36 & -0.14 & -0.39 \\
\hline State/private domestic & -0.27 & -0.55 & & & 2.23 & $1.73+$ & & \\
\hline State/private foreign & -0.32 & -0.82 & & & 0.76 & 1.03 & & \\
\hline State/private foreign/ domestic & -0.46 & -0.77 & & & & & & \\
\hline Formal debt/capital & 0.92 & $2.95 * *$ & 0.65 & $1.82+$ & 1.61 & $2.92 * *$ & 1.68 & $3.51 * *$ \\
\hline formal debt/capital squared & -0.26 & $-1.89+$ & -0.13 & -0.87 & -0.45 & $-2.12 *$ & -0.54 & $-2.89 * *$ \\
\hline Informal debt/capital & 0.01 & 0.06 & -002 & -0.08 & & & & \\
\hline Overdraft/capital & 0.05 & 0.55 & -0.17 & -1.18 & -0.50 & -1.61 & -0.27 & -1.08 \\
\hline Access to overdraft? & -0.21 & $-1.67+$ & 0.04 & 0.40 & 0.82 & $3.35 * *$ & 0.82 & $3.62 * *$ \\
\hline Pred. profit/capital ratio & & & 0.00 & 0.00 & 1.37 & $2.43 * *$ & 1.34 & $2.38 *$ \\
\hline Profit/capital ratio & 0.02 & 0.39 & 0.04 & 0.80 & & & & \\
\hline Mandated investment & -0.05 & -0.68 & 0.00 & -0.01 & & & & \\
\hline Micro firm & 0.20 & 0.85 & 0.26 & 0.99 & -2.97 & $-3.52 * *$ & -2.53 & $-4.22 * *$ \\
\hline Small firm & -0.07 & -0.43 & -0.04 & -0.22 & -1.03 & $-2.98 * *$ & -0.96 & $-3.05 * *$ \\
\hline Medium firm & -0.32 & $-2.17 *$ & -0.29 & -1.59 & -0.72 & $-2.62 * *$ & -0.61 & $-2.19 *$ \\
\hline Firm age & -0.01 & $-2.48 *$ & -0.01 & $-1.72+$ & 0.00 & 0.07 & 0.00 & 0.08 \\
\hline Accounts? & -0.49 & $-3.34 * *$ & -0.56 & $-3.57 * *$ & 0.71 & $2.33 *$ & 0.70 & $2.65 * *$ \\
\hline Firm in capital city? & -0.04 & -0.37 & -0.17 & -1.30 & 0.40 & $1.71+$ & 0.44 & $1.98+$ \\
\hline Age owner & & & 0.00 & 0.27 & & & -0.01 & -1.08 \\
\hline Born in this town? & & & 0.00 & -0.01 & & & 0.08 & 0.26 \\
\hline Time spent in this town & & & 0.00 & -1.19 & & & 0.01 & 1.04 \\
\hline Own other business? & & & 0.30 & $2.25 *$ & & & -0.41 & $-1.92+$ \\
\hline Sex owner & & & 0.67 & $2.28 *$ & & & 0.00 & 0.01 \\
\hline Other business in sector? & & & 0.16 & 1.09 & & & 0.12 & 0.50 \\
\hline Own house, vehicle, farm? & & & -0.11 & -0.74 & & & -0.14 & -0.54 \\
\hline Zimbabwe & 0.08 & 0.53 & 0.09 & 0.47 & -0.26 & -0.83 & -0.31 & -0.91 \\
\hline Cameroon & 0.69 & $3.71 * *$ & 0.69 & $2.89 * *$ & -1.07 & $-2.78 * *$ & -1.18 & $-2.76 * *$ \\
\hline Ghana & 0.55 & $3.27 * *$ & 0.60 & $2.74 * *$ & -0.59 & -1.86 & -0.86 & $-2.33 * *$ \\
\hline Cote d'Ivoire & 0.80 & $3.42 * *$ & 0.57 & $1.82+$ & -1.94 & $-2.65 * *$ & -2.62 & $-3.04 * *$ \\
\hline Burundi & 0.11 & 0.37 & 0.30 & 0.82 & -1.13 & $-1.76+$ & -1.05 & -1.63 \\
\hline Constant & 0.30 & 0.91 & -0.29 & -0.48 & -1.67 & $-2.37 *$ & -0.47 & -0.43 \\
\hline Observations (groups) & 132 & $(785)$ & 985( & 585) & 551 & $(420)$ & 440 & (333) \\
\hline Test on $\rho$ (heterogeneity) ${ }^{a}$ & $\chi^{2}(1)=$ & $21.16 * *$ & $\chi^{2}(1)=$ & $12.45 * *$ & $\chi^{2}(1)=$ & 1.42 & $\chi^{2}(1)=$ & 0.00 \\
\hline Wald joint significance & $\chi^{2}(36)=$ & $135.3 * *$ & $\chi^{2}(38)=$ & $106.9 * *$ & $\chi^{2}(34)=$ & $36.53 * *$ & $\chi^{2}(34)=$ & $113.3^{* *}$ \\
\hline
\end{tabular}

Base groups: private domestic firms, firms with limited liability legal status, Kenya, large firms.

Regression controls also for sectors and for year using dummies.

${ }^{\mathrm{a}}$ This tests the presence of group-wise autocorrelation in the errors, with the null of $\rho=0$.

$* *=$ significant at $1 \%$

$*=$ significant at $5 \%$

$+=$ significant at $10 \%$ 
Table 13 Fixed effects logit model (all firms)

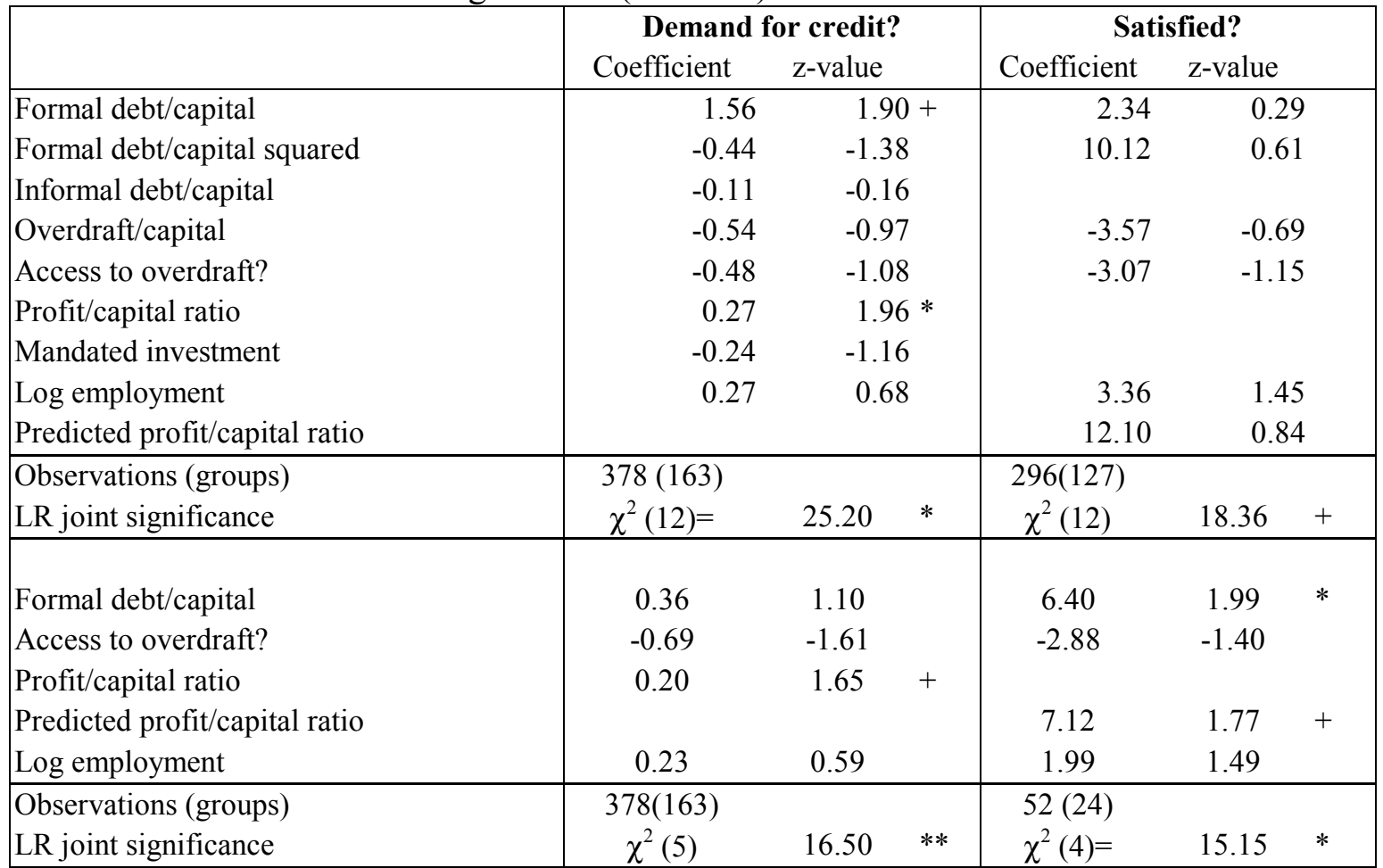

Regression includes year dummies. Note that estimations only use those firms changing status over time

$* *=$ significant at $1 \%$

$*=$ significant at $5 \%$

$+=$ significant at $10 \%$

However, the random effects estimator assumes that the heterogeneity is not correlated with other variables in the regression. Since this may not be correct, especially for variables of interest such as the formal debt or size variables, it is useful to consider fixed effects estimators as well. Table 13 reports the fixed effects logit models for the demand for external finance and the question whether this demand is satisfied. Relatively few firms report a change in the left hand side variables (especially on having credit demand satisfied), so to retain sufficient degrees of freedom, we restricted the explanatory variables, based on some experimentation, such as excluding some variables systematically insignificant in the other regressions. The size dummies were replaced by the log of employment. We also report an even more restricted model, retaining only significant or nearly significant variables in the first regression. Despite the small data set, some of the earlier results appear quite robust when looking at credit allocation. In particular, when looking at all firms, predicted profitability appears to play a positive role in the bank's allocation rules. Furthermore, the effect of outstanding formal debt is retained as well. Employment is only significant at 12 percent, but given the small sample this means it cannot easily be discarded, especially since this specification controls for fixed effects: relatively small movements in employment appear to affect the probability of obtaining credit when demanded ${ }^{18}$. This would give support for the view that firm size in itself is a

\footnotetext{
${ }^{18}$ Calculating marginal effects from the fixed effects logit model is not self-evident since the probability of a particular outcome (and therefore the marginal effects) still contain the firm-specific fixed effects in a non-linear function.
} 
source of bias in credit allocation: a change in employment in a relatively short period affects the probability of banks allocating credit. Since this finding is present after controlling for observed and unobserved underlying characteristics of firms, it is less likely to be a reflection of relatively high transactions costs on the part of banks to allocate loans to these smaller firms ${ }^{19}$.

Another way of looking at the firm size effect is to consider the way banks appear to require a small firm to have a higher (predicted) profitability before they offer a loan to it, compared to a larger firm. Table 14 and figure 1 illustrate this, based on the conditional results of the sample selection specification. For a firm with mean characteristics, the probability that it will obtain a loan when it desires is about 21 percent. Keeping other characteristics constant, a medium firm would need a profitability ratio of 56 percent, but this increases to more than 200 percent for a micro firm. A large firm would in this case even get a loan with this probability when its profit/capital ratio would be minus 8 percent. Similar differences are obtained at higher probabilities of receiving a loan. Figure 1 shows this relationship as well, but this time from a slightly different specification in which the size dummies are replaced with the $\log$ of employment in the sample selection model, allowing a smooth relationship between predicted profitability needed and firm size. For large firms, expected profitability seems not at all important, while for small and micro firms, the required profitability increases fast. The higher demands imposed on small and micro firms in allocating loans is a sign of a bias against them.

Table 14

Predicted profitability relative to firm size

\begin{tabular}{|c|c|c|c|}
\hline \multirow{2}{*}{ firm size (number } & \multicolumn{3}{|c|}{ predicted profitability (profit over capital ratio) } \\
& \multicolumn{2}{|c|}{ needed to receive a loan with probability of } \\
& 21 percent & 31 percent & 42 percent \\
\hline micro (1-5) & 2.08 & 2.46 & 2.83 \\
small (6-25) & 0.69 & 1.06 & 1.44 \\
medium (26-100) & 0.56 & 0.93 & 1.31 \\
large (100+) & -0.08 & 0.30 & 0.67 \\
\hline
\end{tabular}

Source: calculated from regression for all firms (sample selection model in table 11)

The systematic relationship between obtaining credit in a particular year and outstanding formal debt remains striking. While the effect is non-linear and at very high values of indebtness becomes negative, there is wide interval of values for which debt appears to help access to loans, which is not in line with expectations. One possible interpretation is that the lending market is hard to penetrate but, once entered, it provides systematic access to credit. Long-term relationships between firms and banks could be a source of improved information and trust. However, while possibly reflecting long-term relationships, high debt over capital ratios can hardly be viewed positive signs of creditworthiness, as the actual banking screening rule appears to suggest. This hysteresis effect may be a reflection of inefficiency in the formal credit market. In the end, it shows that there is too much lending for some types of firms.

\footnotetext{
${ }^{19}$ This would not be a sign of a bias if costs are directly related to firm size and not related to unobserved characteristics that are typically present in small firms. Of course, we cannot exclude this possibility so that the evidence is still only suggestive rather than conclusive.
} 
Personal relationships between firms and banks could also provide a source of reduced transactions and monitoring costs. Unfortunately, the data does not include much information that could be used for this purpose, while variables such as being born in the current town of residence and how long one has lived in this town appear not significant. In the data, with the exception of the Ghana survey rounds used, information on the ethnic background (broadly defined) of firm owners was also collected. Applying the basic sample selection model for the remaining countries, but this time including ethnicity, we found that in credit allocation these factors play a role. In particular, firms owned by Africans have more often a demand for external finance, probably suggesting that the other groups (firms owned by European, Middle Eastern or Asian enterpeneurs) have access to alternative sources (significant at 1 percent). Asian firm owners typically have a 25 percent higher probability to obtain credit than African owners (significant at 5 percent). Most Asian firm owners in the sample live in Kenya. Here, Asian businessmen are typically well connected: they can rely on their networks to obtain credit outside the financial sector, but they also have networks within the financial sector, so that if they demand credit, they have a relatively high probability to obtain the loan ${ }^{20}$.

Thusfar, we only reported the results for the data set in which data for all countries are pooled, allowing for a constant different effect per country. How robust are our key results across countries? We conducted a set of pooling likelihood ratio tests in the form of linear restrictions on more a general formulation of model, in which the formal debt ratio, firm size and predicted profit were interacted with country dummies. We used the sample selection model for this purpose ${ }^{21}$. Both on these three variables as a group or separately, we find that the country-level interactions are not significant $^{22}$.

This does not mean that there are no country-level effects: relative to Kenya, the regressions in table 11 and 12 systematically report more firms not obtaining credit when desired in Ghana, Côte d'Ivoire and Cameroon. The pooling tests reported before suggest that the explanation cannot be found in a different bank screening policy towards expected profitability, firm size and formal sector debt. The country effects are shifters in the probability of obtaining credit, valid for all types of firms. To put some meaning to these different country effects, we repeated the regressions on whether credit demand is satisfied but this time replacing the country dummies by the continuous characteristics reported in table 1. While interest rates and growth in GDP was not significant, we found a significant effect on M2 over GDP, a measure of financial deepening. In the sample selection model, the marginal effect suggested that a one percent in increase in M2/GDP would result in a 1.4 percent higher probability that a typical firm would obtain credit when demanded. A large part of the difference

\footnotetext{
${ }^{20}$ Raturi and Swamy (1997) convincingly analyse this issue further for Zimbabwe, focusing on whether the observed patterns are reflecting discrimination.

${ }^{21}$ Expanding the number of explanatory variables for this purpose resulted in problems of convergence in the random effects model. Also, since in the final data set with complete information, not all countries have firms in each group with a demand for credit, the size dummies were replaced by the log of employment. In the restricted regression, this variable was significant with a t-value of more than 5 , providing again strong evidence of a positive correlation between high debt and access to loans.

${ }^{22}$ The likelihood ratio test on the restrictions could not be rejected at 8 percent (log employment), 3 percent (predicted profitability), 1 percent (debt over capital ratio) or at 1 percent (all three).
} 
between countries picked up by the country dummies appears to be explained by this variable, since the Pseudo $\mathrm{R}^{2}$ on the regression only drops from 0.35 to 0.34 when the country and year dummies are dropped and replaced by this continuous variable. In other words, differences in financial deepening between countries such as Kenya or Zimbabwe relative to Ghana or Burundi appear to explain some of the differences in credit demand approvals in the sample.

However, differences in financial deepening or other characteristics between countries cannot explain the differential treatment of firms of different sizes in the credit market. As a consequence, the credit allocation practices biasing against smaller firms can only be linked to factors that are present across these different countries: for example, information problems or problems related to contract enforcement, including problems with property rights affecting access to collateral. Some of these issues are known to be problematic across African countries in general. Collier and Gunning (1999) have pointed to higher risk of contract default in Africa than in other regions due to less trustworthy accounts or problems to physically honour contracts on time in economies with poor transport and other infrastructure. The lack of a financial press or the absence of credit-rating agencies - linked to the small size of the economies involved - make financial information costs very high. Serious problems with property rights, such as land in many countries, reduce the options for using collateral. These factors may well explain some of the bias against credit allocation by the banks. If so, note that intervention in credit markets, for example via targeted credit allocation to smaller firms, may not be successful without addressing these underlying problems of high risk and poor information in African credit markets.

\section{Conclusions}

We investigated the question whether firms in the manufacturing sector in Africa are credit constrained. The fact that few firms obtain credit is not sufficient to prove constraints, since certain firms may not have a demand for credit while others may be refused credit as part of profit maximising behaviour by banks. To investigate this question, we use direct evidence on whether firms had a demand of credit and whether their demand was satisfied in the formal credit market, based on panel data on firms in the manufacturing sector from six African countries.

We find that more than half the firms in the sample had no demand for credit. Of those firms with a demand for credit, only a quarter obtained a formal sector loan. In line with expectations, our analysis suggests further that banks allocate credit on the basis of expected profits. However, controlling for credit demand, outstanding debt is positively related with obtaining further lending while micro, small and medium sized firms are less likely to get a loan. The latter effect is strong and present in the regression, despite including several variables typically referred to as explaining why small or 'informal' firms do not get credit. These include whether the firm keeps accounts, information on assets owned by the owner, residency and location.

The role of outstanding debt is likely to be a reflection of inefficiency in credit markets, while the fact that size matters is consistent with a bias against smaller firms. The former would suggest too much, the latter too little lending on the part of banks. 
Although we cannot exclude that these effects reflect transactions costs on the part of banks, some of the evidence does not favour this interpretation. Finally, we could not detect any differences between countries in the effects of these factors in the credit allocation rule, although financial deepening is found to explain most of the countryspecific fixed effects, shifting the probability of obtaining credit across the firm distribution.

\section{References}

Biggs, T. and P. Srivastava (1997), "Structural Aspects of Manufacturing in SubSaharan Africa, Findings from a Seven Country Enterprise Survey", World Bank Discussion Paper no.348, Africa Technical Department Series, The World Bank.

Bigsten, A., P.Collier, S.Dercon, B.Gauthier, J.W.Gunning, A.Isaksson, A.Oduro, R.Oostendorp, C.Pathillo, M.Söderbom, M.Sylvain, F.Teal and A.Zeufack, (1999a), Investment in Africa's Manufacturing Sector: a Four Country Panel Data Analysis", Oxford Bulletin of Economics and Statistics, November.

Bigsten, A., P.Collier, S.Dercon, M.Fafchamps, B.Gauthier, J.W.Gunning, A.Oduro, R.Oostendorp, C.Pathillo, M.Söderbom, F.Teal and A.Zeufack, (1999b), "Adjustment Costs, Irreversibility and Investment Patterns in African Manufacturing”, IMF Working Paper, WP/99/99, Research Department, International Monetary Fund, Washington D.C.

Bond, S. and C. Meghir, "Dynamic Investment Models and the Firm's Financial Policy”, Review of Economic Studies, vol.61, April, pp.147-222.

Caballero, R.J., E.M.Engel and J.C.Haltiwanger (1995), "Plant-Level Adjustment and Aggregate Investment Dynamics", Brookings Papers on Economic Activity no.2, Brookings Institution, pp.1-39.

Collier, P. and J.W.Gunning (1999), "Explaining African Economic Performance", Journal of Economic Literature, vol. XXXVII, No.1, pp.64-111.

Cuevas, C., M.Fafchamps, R.Hanson, P.Moll and P.Srivastava (1993), "Case Studies of Enterprise Finance in Ghana", final report, Regional Program on Enterprise Development, The World Bank.

Dercon, S. and L.Ayalew, (1994), "Credit and the manufacturing sector in Burundi", chapter 6 in Catholic University Leuven and Université de Burundi, The Structure, Performance and Development of the Manufacturing Sector in Burundi, RPED report.

Dercon, S., (1995), "Credit Constraints in the manufacturing sector in Côte d'Ivoire", mimeo, K.U.Leuven and Centre for the Study of African Economies.

Fafchamps, M., J.Pender and E.Robinson (1995), "Enterprise Finance in Zimbabwe", Regional Program on Enterprise Development, The WorldBank. 
Fafchamps, M., (1997), "Trade Credit in Zimbabwean Manufacturing", World Development, vol.25, no.5, May, pp.795-815.

Fafchamps, M. (2000), "Ethnicity and Credit in African Manufacturing", Journal of Devleopment Economics, vol.61, pp.205-235.

Fazzari, S., R.G. Hubbard and B.Peterson (1988), "Financing Constraints and Corporate Investment”, Brooking Papers Economic Activity, pp.141-195.

Fisman, R. (1998), "Financing the free lunch: Trade Credit and Productive Efficiency in Developing Economies", mimeo, Harvard University.

Gilchrist, S. (1991), “An Empirical Analysis of Corporate Investment and Financing Hierarchies Using Firm-Level Panel Data", mimeo, Board of Governors of the Federal Reserve System.

Gunning, J.W. and C.Mumbengegwi (1995), Final Report on the round II RPED Survey Data, Free University Amsterdam and University of Zimbabwe.

Greene, W.H., (1993), Econometric Analysis, Second Edition, Macmillan Publishing Company, New York.

Hoff, K.R., A.Braverman and J.E.Stiglitz (1993), The Economics of Rural Organization: Theory, Practice and Policy, Oxford University Press, Oxford University Press for the World Bank.

Hoshi, T., A.Kashyap and D.Scharfstein (1991), "Corporate Structure, Liquidity and Investment: Evidence from Japanese Panel Data, Quarterly Journal of Economics, vol.106, no.1, pp. 33-60.

$\mathrm{Hu}, \mathrm{X}$. and F.Schiantarelli, (1998), "Investment and Capital Market Imperfections: a switching regression approach using U.S. firm panel data", Review of Economics and Statistics, pp. 466-479.

Hubbard, G.R., (1998), "Capital-Market Imperfections and Investment”, Journal of Economic Literature, March, XXXVI(1), pp.193-238.

Hubbard, R.G., A.Kashyap and T.Whited (1995), "Internal Finance and Firm Investment", Journal of Money, Credit and Banking, August, 27 (4), pp.683701.

Kaplan, S. and L.Zingales (1997), "Do Financing Constraints Explain Why Investment is Correlated With Cash Flow?", Quarterly Journal of Economics, February, vol.112, no.1, pp.169-216.

Maddala, G.S., (1987), "Limited Dependent Models using Panel Data", Journal of Human Resources, vol.22, no.3, pp.307-338. 
Nabi, I. (1989), "Investment in Segmented Capital Markets", Quarterly Journal of Economics, vol.104, no.3, August, pp.453-62.

Raturi, M. and A.V. Swamy (1999), "Explaining Ethnic Differentials in Credit Market Outcomes in Zimbabwe", Economic Development and Cultural Change, pp.585-604.

Sciatarelli, F. (1996), "Financial Constraints and Investment: Methodological Issues and International Evidence", Oxford Review of Economic Policy, vol.12, no.2, pp.70-89.

Soyibo, A. (1997), "Financial Liberalisation and Bank Restructuring in Sub-Saharan Africa: Some Lessons for Sequencing and Policy Design", Journal of African Economies, vol.6, no.1, AERC Supplement, pp.100-150.

Tybout, J. (1983), "Credit Rationing and Investment Behaviour in a Developing Country", Review of Economics and Statistics, vol.65, no.4, pp.598-607. 
Appendix 1: Survey dates

Table A.1 Years to which data apply

\begin{tabular}{|l|c|c|c|c|c|}
\hline & 1991 & 1992 & 1993 & 1994 & 1995 \\
\hline Ghana & $\mathrm{x}$ & $\mathrm{x}$ & $\mathrm{x}$ & & \\
Côte d'Ivoire & & & & $\mathrm{x}$ & $\mathrm{x}$ \\
Burundi & & $\mathrm{x}$ & & & \\
Zimbabwe & & $\mathrm{x}$ & $\mathrm{x}$ & $\mathrm{x}$ & \\
Kenya & & $\mathrm{x}$ & $\mathrm{x}$ & $\mathrm{x}$ & \\
Cameroon & & & $\mathrm{x}$ & $\mathrm{x}$ & $\mathrm{x}$ \\
\hline
\end{tabular}

Appendix 2: Desired capital stock and mandated investment

Caballero et al. (1995) define mandated investment as the deviation between desired and actual capital:

$$
(\mathrm{I} / \mathrm{K})_{\mathrm{it}}{ }^{\text {MANDATED }}=\mathrm{k}_{\mathrm{it}}{ }^{*}-\mathrm{k}_{\mathrm{it}-1}
$$

where $\mathrm{k}_{\mathrm{it}}{ }^{*}$ and $\mathrm{k}_{\mathrm{it}-1}$ are the log of desired and actual capital. Desired capital, the stock that firms would hold if adjustment costs were temporarily removed, is equal to frictionless capital, the stock would hold if they never faced adjustment costs, plus a firm specific constant.

To estimate desired capital, we follow the procedure explained in Bigsten et al. (1999b). Since desired capital equals frictionless capital plus a firm-specific constant, we estimate the log of desired capital as a function of log output and a firm specific constant using fixed effects. We impose no restrictions on the output elasticity. However, desired capital is not observable. Following Caballero et al. (1995), we assume that deviations from desired and actual capital stock are stationary over time. Consequently, we can use the actual stock series and interpret the regression as determining long-run desired capital. Our measure of the firm's desired capital is the predicted value from this regression.

Note that to calculate mandated investment using desired capital, we need to use the capital stock in the previous. This would result in the loss of a further observation. To avoid this, in our calculations of mandated investment, we used the capital stock net of investment in the current year as a measure of capital in the beginning of the current year, so that no further observation is lost. 


\section{Appendix 3: The Decision to Apply for a Loan}

While the main results will be obtained using these binary models, we report another test on the model structure. In the paper, we argued that the division of firms into groups according to demand for external funds and whether the demand was met is more appropriate to investigate credit market constraints than simply looking at whether firms apply and whether applications are approved. Effectively, this means that the group facing credit market constraints include both firms not applying but with an apparent credit demand as well as firms applying but not receiving the loan. In the theoretical framework, we allowed that firms may prefer external over internal funds ((a), (b) and (c) on page 7), but did not apply because of low perceived success rate, lack of collateral or high application costs ((d) and (e) on page 8). Our empirical approach of pooling firms applying and not applying in one group, if they appear to have a demand for external funds, can be tested.

We run the model for the demand for credit using a multinomial logit model with four options and test whether pooling is appropriate between the groups using a test of restrictions $^{23}$. In particular, we divide the firms in four sub-sets: A,B,C,D. Those applying and receiving are in D. Those applying and not receiving a loan are in $\mathrm{C}$, those not applying are in $A \cup B$. Those not wanting a loan are in $A$, while those wanting a loan but not applying are in B. Consequently, those firms 'constrained' in the credit market are in $\mathrm{B} \cup \mathrm{C}$. The test of interest is then the pooling of $\mathrm{B}$ and $\mathrm{C}$ in the model.

We used the full list of variables used in the estimations of (12). It turned out that pooling of the two regimes is just rejected at 1 percent. However, adding a shifter for micro-firms, pooling is possible at 2 percent for all firms and at 6 percent for privately owned firms. The relative value of the coefficients on the dummy for micro firms suggests that micro firms are less likely to actually apply even if they have a demand for credit. This could be a reflecting of concave transactions costs for loan applications, implying relatively high costs for a firm operating on a very small scale. However, it may also be a consequence of the low perceived success rate for such firms - a perception which turned out to be correct according to our subsequent analysis. Note that the descriptive analysis in table 7 suggests that the perceived low chances of obtaining a loan are the main reason, not difficulties and costs of the process.

Another means of testing this confirmed these findings. Conditioning on firms that expressed a demand for external funds, we did a probit regression on whether firms actually applied or not, using the same variables as in the model for the demand for external funds. Micro-firms with a demand for external funds were 46 percent less likely to apply for loans and this effect was significant at 1 percent. The coefficient on small firms was only significant at 10 percent and on medium firms was not significant.

\footnotetext{
${ }^{23}$ Note that the distributional and other assumptions of the multinomial logit are different from those used in the bivariate probit. However, using an alternative model, such as the multinomial probit with sample selection to test the pooling of the groups is not feasible, since it would involve the evaluation of complex higher order multivariate normal integrals (for a discussion, see Greene, p.663).
} 
High transactions costs for certain firms imply a deviation an inefficiency in credit markets. However, to the extent that limited loan applications by micro-firms are simply a consequence of these relatively high transactions costs when applying for a small loan, it is hard to see how intervention may correct this failure. The findings also suggest that the subsequent bias against micro or small firms in terms of credit allocation, in the sense of an unwarranted exclusion of these firms from credit, is smaller than predicted.

Finally, our results from the pooling tests in this appendix does not suggest that transactions costs are relatively high for small and medium firms relative to large firms. Since our results on credit allocation in section 5 suggest that small or medium firms also face a bias, distinguishing an additional stage in the decision model (12) to model applications, is not likely to change the overall findings. 


\section{Appendix 4 : Predicted Profits}

Table A.2 Prediction model profits rate (profits over capital) $(\mathrm{n}=1321)$

\begin{tabular}{|c|c|c|}
\hline & coefficient & t-value \\
\hline wood sector & 0.01 & 0.16 \\
\hline textile sector & -0.02 & -0.29 \\
\hline metal sector & -0.16 & $-1.81+$ \\
\hline state sector & 0.10 & 0.26 \\
\hline solo firm & 0.16 & $1.79+$ \\
\hline Partnership & -0.01 & -0.06 \\
\hline Private corporation & -0.19 & -1.55 \\
\hline State corporation & -0.44 & -1.32 \\
\hline Subsidiary domestic firm & -0.09 & -0.42 \\
\hline State/private domestic firm & 0.14 & 0.56 \\
\hline Subsidiary foreign & 0.13 & 0.58 \\
\hline Private foreign firm & 0.01 & 0.09 \\
\hline Private domestic firm & 0.07 & 0.72 \\
\hline State/private domestic firm & -0.32 & -0.99 \\
\hline State/private, domestic and foreign firm & -0.06 & -0.16 \\
\hline Capital city? & -0.08 & -0.51 \\
\hline Ghana*wave 1 & 0.15 & 0.66 \\
\hline Ghana*wave 2 & -0.09 & -0.52 \\
\hline Ghana*wave 3 & -0.20 & -1.22 \\
\hline Cote d'Ivoire*wave 1 & 0.35 & 1.78 \\
\hline Cote d'Ivoire* wave 2 & 0.82 & $4.20 * *$ \\
\hline Cameroon*wave 1 & 0.26 & 1.21 \\
\hline Cameroon*wave 2 & -0.03 & -0.14 \\
\hline Cameroon*wave 3 & -0.17 & -0.84 \\
\hline Kenya*wave 1 & -0.04 & -0.23 \\
\hline Kenya*wave 2 & -0.03 & -0.17 \\
\hline Kenya*wave 3 & -0.15 & -0.94 \\
\hline Burundi & 0.02 & 0.11 \\
\hline Zimbabwe*wave 2 & -0.03 & -0.23 \\
\hline Zimbabwe*wave 3 & 0.06 & 0.39 \\
\hline micro firm & 0.31 & $2.29 *$ \\
\hline small firm & 0.11 & 1.04 \\
\hline medium firm & 0.06 & 0.66 \\
\hline constant & 0.75 & $4.23 * *$ \\
\hline $\begin{array}{l}\text { Further controls for location (towns) incl } \\
\text { Joint significance } F(45,1275)=2.57^{*} \\
\text { R-squared }=0.083 \\
\text { Adj R-squared }=0.051\end{array}$ & & \\
\hline
\end{tabular}

$* *=$ significant at $1 \%$

$*=$ significant at $5 \%$

$+=$ significant at $10 \%$ 
Figure 1 Iso-probability lines

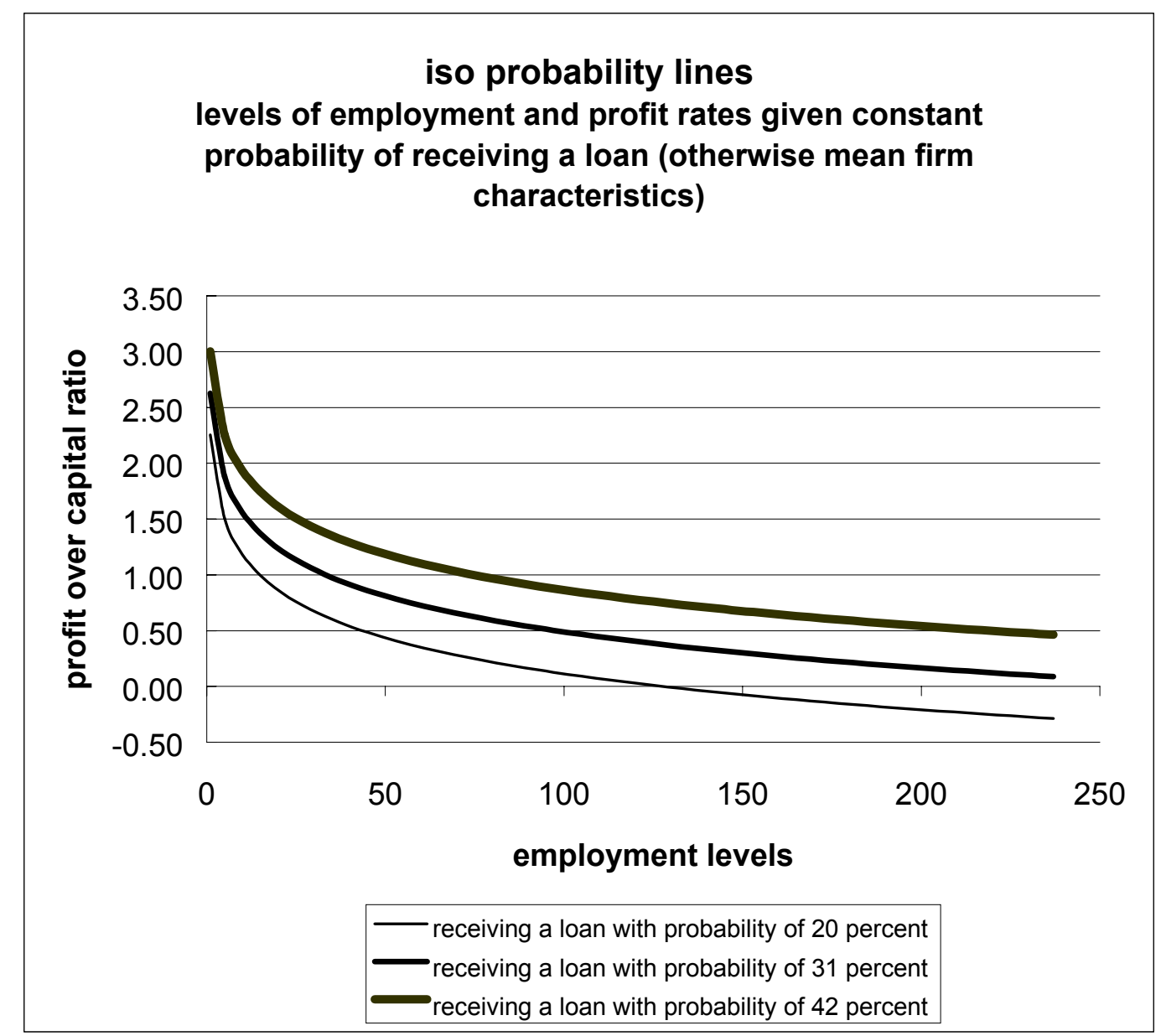

Source: calculated from regression for all firms (sample selection model in table 11), but replacing size dummies with $\log$ of employment to obtain smooth relationship. 